\title{
Evidence for a Role of the Chemorepellent Semaphorin III and Its Receptor Neuropilin-1 in the Regeneration of Primary Olfactory Axons
}

\author{
R. Jeroen Pasterkamp, Fred De Winter, Anthony J. G. D. Holtmaat, and Joost Verhaagen \\ Graduate School for Neurosciences Amsterdam, Netherlands Institute for Brain Research, 1105 AZ Amsterdam-ZO, \\ The Netherlands
}

To explore a role for chemorepulsive axon guidance mechanisms in the regeneration of primary olfactory axons, we examined the expression of the chemorepellent semaphorin III (sema III), its receptor neuropilin-1, and collapsin response mediator protein-2 (CRMP-2) during regeneration of the olfactory system. In the intact olfactory system, neuropilin-1 and CRMP-2 mRNA expression define a distinct population of olfactory receptor neurons, corresponding to immature (B-50/GAP-43positive) and a subset of mature (olfactory marker proteinpositive) neurons located in the lower half of the olfactory epithelium. Sema III mRNA is expressed in pial sheet cells and in second-order olfactory neurons that are the target cells of neuropilin-1-positive primary olfactory axons. These data suggest that in the intact olfactory bulb sema III creates a molecular barrier, which helps restrict ingrowing olfactory axons to the nerve and glomerular layers of the bulb. Both axotomy of the primary olfactory nerve and bulbectomy induce the formation of new olfactory receptor neurons expressing neuropilin-1 and CRMP-2 mRNA. After axotomy, sema III mRNA is transiently induced in cells at the site of the lesion. These cells align regenerating bundles of olfactory axons. In contrast to the transient appearance of sema III-positive cells at the lesion site after axotomy, sema III-positive cells increase progressively after bulbectomy, apparently preventing regenerating neuropilin-1-positive nerve bundles from growing deeper into the lesion area. The presence of sema III in scar tissue and the concomitant expression of its receptor neuropilin-1 on regenerating olfactory axons suggests that semaphorin-mediated chemorepulsive signal transduction may contribute to the regenerative failure of these axons after bulbectomy.

Key words: CNS; CRMP; olfactory bulb; olfactory receptor neuron; neuropilin; plasticity; primary olfactory system; regeneration; semaphorin/collapsin
The adult olfactory neuroepithelium is a unique neural tissue, because it has retained its capacity to replace dying neurons with new neurons formed by cell division from stem cells in the basal region of the epithelium (for review, see Graziadei and Monti Graziadei, 1978; Graziadei, 1990; Farbman, 1990, 1992). These new olfactory neurons extend axons penetrating the cribriform plate and entering the CNS, where they continue to grow through the growth-permissive nerve layer of the olfactory bulb until they have entered the glomerular neuropil, where they stop growing to form synapses on the processes of second-order olfactory neurons (see Fig. 1) (for review, see Farbman, 1992). The primary olfactory system also has a remarkable capacity to recover from injury. After axotomy of the primary olfactory nerve, new olfactory receptor neurons regenerate into the CNS, establishing synaptic contacts with their target neurons (Harding et al., 1977; Monti Graziadei and Graziadei, 1979; Graziadei and Monti Graziadei, 1980; Doucette et al., 1983; Constanzo, 1985). Removal of the olfactory bulb (bulbectomy) also induces neurogenesis. However, in adult rodents, bulbectomy results in the formation of a neural

Received Aug. 5, 1998; revised Sept. 8, 1998; accepted Sept. 10, 1998.

This work was supported by a Nederlandse Organisatie voor Wetenschappely̌k Onderzcoek-Gebied Medische Wetenschappen Pioneer Grant and grants from the Van Den Houten Fonds and the Koninkly̌ke Nederlandse Akademie van Wetenschappen Vernieuwingsfonds. We thank Gerben van der Meulen for his help with the photographic work. We also thank Bob Baker and Guus Wolswijk for careful review and discussion of this manuscript.

Correspondence should be addressed to Joost Verhaagen, Netherlands Institute for Brain Research, Meibergdreef 33, 1105 AZ Amsterdam-ZO, The Netherlands. Copyright (C) 1998 Society for Neuroscience $0270-6474 / 98 / 189962-15 \$ 05.00 / 0$ scar, which prevents regenerating olfactory fibers from reaching the cortex (Monti Graziadei, 1983; Hendricks et al., 1994).

Cell adhesion and extracellular matrix (ECM) proteins are abundantly expressed in the developing and mature olfactory system and help to establish and maintain the complex connections between the olfactory epithelium and the olfactory bulb (Miragall et al., 1988, 1989; Doucette, 1990, 1996; Chung et al., 1991; Miragall and Dermietzel, 1992; Gonzalez et al., 1993; for review, see Mori, 1993; Gong and Shipley, 1995, 1996; Treloar et al., 1996; Whitesides and LaMantia, 1996; Yoshihara and Mori, 1997; Yoshihara et al., 1997; Julliard and Hartmann, 1998; Kafitz and Greer, 1998). In addition to these growth-promoting factors, recent evidence suggests a role for chemorepulsive proteins and their receptors in the patterning and maintenance of the primary olfactory pathway (Giger et al., 1996; Sheperd et al., 1996; Zhang et al., 1996; Kobayashi et al., 1997; Livesey and Hunt, 1997; Williams-Hogarth et al., 1997; Yoshida et al., 1997). Growth cones of cultured embryonic olfactory receptor neurons collapse after exposure to the chemorepellent semaphorin III(D)/ collapsin-1 (sema III) (Kobayashi et al., 1997), a member of a family of proteins, some of which function in repulsive axon guidance (Kolodkin et al., 1992, 1993; Luo et al., 1993, 1995; Püschel et al., 1995; Püschel, 1996). Developing olfactory receptor neurons express neuropilin-1 (Satoda et al., 1995; Kawakami et al., 1996), a sema III receptor (Feiner et al., 1997; He and Tessier-Lavigne, 1997; Kolodkin et al., 1997; for review, see Kolodkin and Ginty, 1997), and collapsin response mediator protein-2 (CRMP-2; also known as TOAD-64), an intracellular 


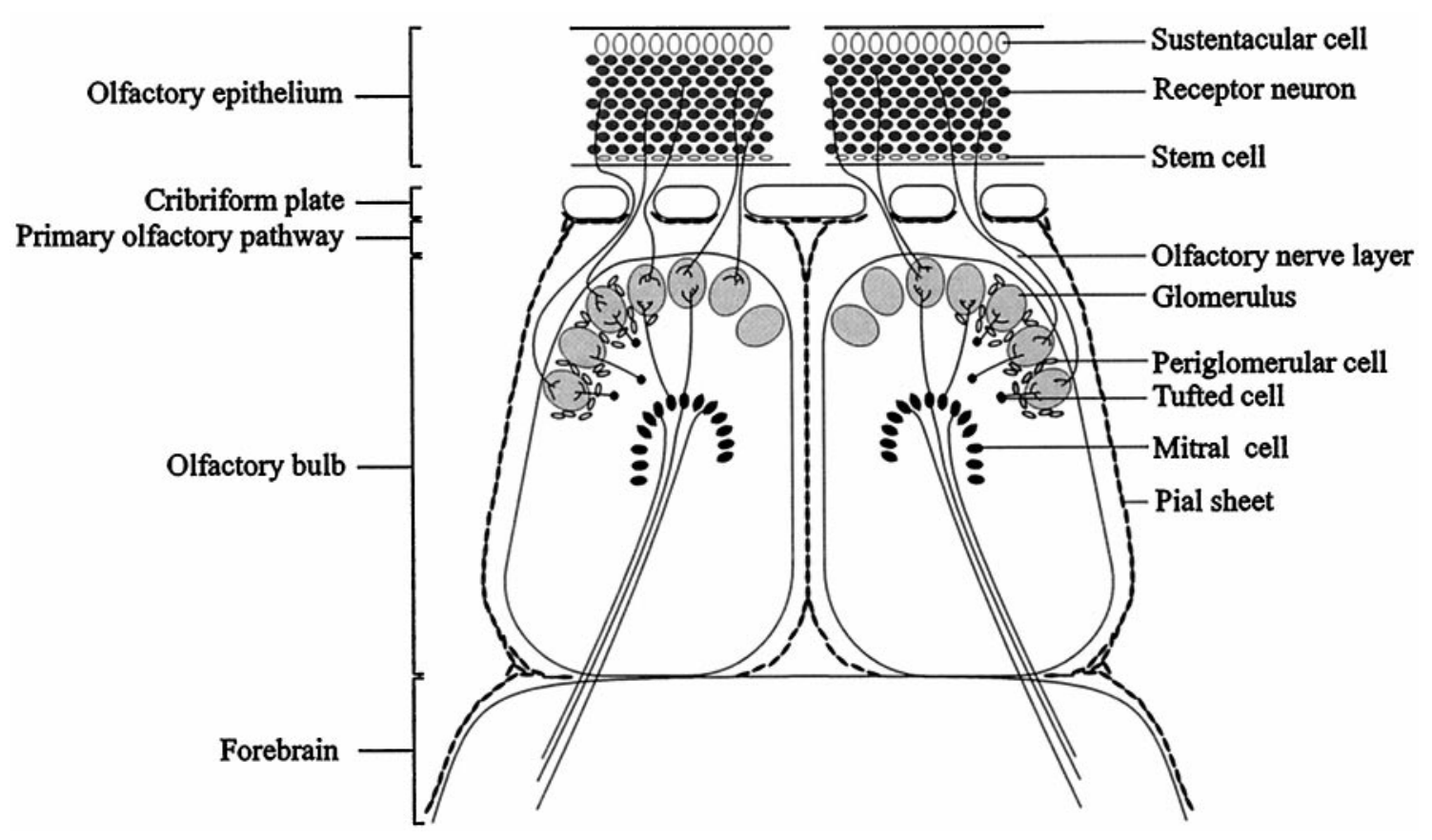

Figure 1. Illustration of the anatomical relationships in the primary olfactory system. The cell bodies of olfactory receptor neurons are located in the olfactory epithelium of the nasal cavity and project their axons through the cribriform plate into the olfactory bulb glomeruli, where they terminate on the processes of second-order olfactory neurons: the mitral, tufted, and periglomerular cells. Throughout life, olfactory receptor neurons are replaced continuously from a population of stem cells located in the basal region of the epithelium. As a consequence, newly formed olfactory axons are constantly being extended toward their targets in the main olfactory bulb. To gain further insight into the molecular mechanisms underlying axonal regeneration in the primary olfactory pathway, the expression of the chemorepellent semaphorin III, its receptor neuropilin-1, and CRMP-2 were investigated in the primary olfactory pathway after two lesioning procedures: unilateral olfactory bulbectomy and unilateral transection of the primary olfactory nerve. Injury to the primary olfactory nerve results in degeneration and subsequent replacement of olfactory receptor neurons. After transection of the primary olfactory nerve between the cribriform plate and the olfactory bulb, newly formed primary olfactory axons regenerate into the CNS, establishing synaptic contacts with their targets in the olfactory bulb. Removal of the olfactory bulb (bulbectomy) also induces neurogenesis. However, in adult rodents, a neural scar prevents the regenerating primary olfactory fibers from reaching undamaged areas, e.g., the frontal pole of the cortex.

protein mediating sema III-induced growth cone collapse (Goshima et al., 1995; Minturn et al., 1995; Wang and Strittmatter, 1996; Kamata et al., 1998). The embryonic spatiotemporal expression patterns of sema III, neuropilin-1, and CRMP-2 suggest that developing primary olfactory nerve fibers are instructed by sema III to wait at or avoid particular cellular compartments of the olfactory pit and telencephalic vesicle (Giger et al., 1996; Kobayashi et al., 1997).

The regenerative response of the mature olfactory epithelium can be viewed as a recapitulation of ontogeny. It is therefore conceivable that semaphorins and their receptors also play a role in the regeneration of primary olfactory axons. Here, we examined the expression of sema III, neuropilin-1, and CRMP-2 after two types of lesions of the olfactory pathway: bulbectomy and axotomy. We show that after both lesions newly formed olfactory receptor neurons contain high mRNA levels of the sema III receptor neuropilin-1 and CRMP-2. Bulbectomy and axotomy, however, induce a striking differential spatiotemporal expression of sema III mRNA at the site of the lesion. After bulbectomy, sema III mRNA-positive cells fill the bulbar cavity and completely surround regenerating bundles of neuropilin-1-positive olfactory axons, apparently blocking their extension. In contrast, after axotomy, sema III-positive cells show up transiently and define channels through which regenerating olfactory nerve bundles find their way to uninjured parts of the olfactory nerve layer. These observations are consistent with the hypothesis that semaphorin III-neuropilin-1 signaling is involved in governing the regeneration of primary olfactory neurons. The differential pat- terns of sema III expression, as shown here after axotomy and bulbectomy, may be critical to the success or failure of olfactory axon regeneration.

\section{MATERIALS AND METHODS}

\section{Animals and surgical procedures}

All surgical and animal care procedures were performed according to the local guidelines of the Experimental Animal Care Committee. Adult male Wistar rats (225-450 gm; Harlan CPB, Zeist, The Netherlands) were housed in group cages and maintained on a $12 \mathrm{hr}$ light/dark cycle with ad libitum access to food and water.

The anatomical relationships in the olfactory system are schematically shown in Figure 1. Two procedures were used to lesion the primary olfactory pathway: (1) olfactory bulbectomy, i.e., destruction of distal axonal projections and synapses of primary olfactory neurons and their target cells; and (2) transection of the primary olfactory nerve, i.e., axotomy of primary olfactory axons between the cribriform plate and the olfactory bulb, a procedure that causes no direct damage to the olfactory bulb. Rats were anesthetized for aseptic surgery with Hypnorm (0.04 $\mathrm{ml} / 100$ gm, i.m.; Janssen Pharmaceutical Ltd., Oxford, England) and Dormicum (0.08 ml/100 gm, s.c.; Roche Nederland B.V., Mijdrecht, The Netherlands) and subjected to surgery as described below. Buprenorphine hydrochloride (Temgesic) $(0.03 \mathrm{ml} / 100 \mathrm{gm}$, s.c.; Schering-Plow, Amstelveen, The Netherlands) was given postoperatively.

Olfactory bulbectomy. The left olfactory bulb was exposed by removing a square section of frontal bone covering the olfactory bulb $\left( \pm 4 \mathrm{~mm}^{2}\right)$, and the bulb was ablated by suction. Care was taken not to damage the contralateral (right) olfactory bulb or the frontal pole of the cortex. The square piece of frontal bone was replaced to close the ablation cavity, and the skin was sutured. Operated animals were allowed to recover and were killed at $3(n=4), 6(n=3), 10(n=5), 30(n=3)$, and $60(n=4) \mathrm{d}$ after lesion. The extent of olfactory bulbectomy was monitored by macroscopic observation and by histological analysis. 
Transection of the primary olfactory nerve. To expose the interface between the cribriform plate and the olfactory bulb, a groove was drilled at $9.0 \mathrm{~mm}$ rostral to bregma in the left frontal bone covering the olfactory bulb. A slightly bent needle was lowered between the intracranial part of cribriform plate and the olfactory bulb, and several deliberate side-toside movements of the needle were used to section the primary olfactory axons. This procedure resulted in deafferentiation of the olfactory bulb, with reinnervation of the olfactory glomeruli by new primary olfactory axons, which is in line with previous observations (Graziadei and Monti Graziadei, 1980; Doucette et al., 1983; Anders and Hurlock, 1996). Histological changes observed at early postlesion time intervals ( $3 \mathrm{~d}$ ) were used to confirm the efficacy of the lesion procedure. Operated animals were allowed to recover and were killed at $3(n=3), 6(n=3)$, $10(n=4), 30(n=3)$ and $60(n=3) \mathrm{d}$ after lesion.

All animals with partial lesions or with lesion-induced damage in the frontal pole of the cortex were discarded from this study (4 animals). Unoperated age-matched control animals were killed at each of the above indicated postoperative time intervals $(n=15)$.

\section{Tissue preparation}

In situ hybridization and combined in situ hybridization-immunohistochemistry. At the appropriate postoperative survival time, rats were deeply anesthetized with Nembutal (0.125 ml/100 gm, i.p.; Sanofi Sante, Maassluis, The Netherlands) and intracardially perfused with $100 \mathrm{ml}$ of $0.9 \% \mathrm{NaCl}$, followed by $300 \mathrm{ml}$ of $4 \%$ paraformaldehyde (PFA) in $0.1 \mathrm{M}$ PBS, pH 7.4. After perfusion, olfactory epithelia and olfactory bulbs were dissected out and post-fixed for $2.5 \mathrm{hr}$ in $4 \%$ PFA in $0.1 \mathrm{M}$ PBS at $4^{\circ} \mathrm{C}$. Decalcification of the olfactory epithelia with connected olfactory bulbs was performed overnight in a solution containing $250 \mathrm{~mm}$ EDTA and $50 \mathrm{~mm}$ phosphate buffer (PB), pH 7.5, at $4^{\circ} \mathrm{C}$, followed by overnight cryoprotection in $25 \%$ sucrose in $50 \mathrm{~mm} \mathrm{~PB}$ at $4^{\circ} \mathrm{C}$. Tissue blocks were embedded in Tissue-Tek (O.C.T. Compound 4583; Miles, Elkhart, IN) and frozen in dry ice-cooled 2-methylbutane. Consecutive horizontal or transversal cryostat sections $(20 \mu \mathrm{m})$ were subjected to in situ hybridization or double labeling combining in situ hybridization with immunohistochemistry.

Immunohistochemistry. For single immunohistochemical analysis [neuropilin-1 and olfactory marker protein (OMP)], rats were perfused with $100 \mathrm{ml}$ of $0.9 \% \mathrm{NaCl}$, followed by $300 \mathrm{ml}$ of periodate lysine paraformaldehyde fixative (2\% PFA, $0.075 \mathrm{M}$ L-lysine, and $0.214 \%$ sodium metaperiodate) in $50 \mathrm{~mm} \mathrm{~PB}, \mathrm{pH}$ 7.3. After overnight post-fixation in the same fixative, brains were treated with EDTA to enhance tissue penetration, cryoprotected, and frozen.

\section{Reverse transcription-PCR cloning of rat $C R M P-2$}

A cDNA mixture, synthesized by reverse transcription-PCR, of total RNA from embryonic day 15 Wistar rat spinal cord served as a template for the PCR procedure. PCR primers were based on the cDNA sequence of human CRMP-2 [Homo sapiens, European Molecular Biology Laboratories Data bank HS172791 (Wang and Strittmatter, 1996)]. Primers flanked the coding sequence and contained EcoRI and $X b a \mathrm{I}$ restriction sites for subcloning (sense primer 5'-CGGAATTCCACGCATCACGAGCG-3' and antisense primer 5'-GCTCTAGACCAGGCTGGTGATGTTGGC-3', EcoRI and $X b a I$ sites are in italics). The reaction was cycled five times in a cycle profile of $1 \mathrm{~min}$ at $94^{\circ} \mathrm{C}, 30 \mathrm{sec}$ at $55^{\circ} \mathrm{C}$, and $5 \mathrm{~min}$ at $74^{\circ} \mathrm{C}$, followed by 33 times in a cycle profile of $1 \mathrm{~min}$ at $94^{\circ} \mathrm{C}, 30 \mathrm{sec}$ at $70^{\circ} \mathrm{C}$, and $5 \mathrm{~min}$ at $74^{\circ} \mathrm{C}$. The amplified product was purified and subcloned in pBluescript $\mathrm{KS}( \pm)$ vector (Stratagene, La Jolla, CA), using the EcoRI and XbaI sites. The Sequenase 2.0 kit (Amersham, Cleveland, $\mathrm{OH}$ ) was used to confirm the CRMP-2 coding sequence.

\section{In situ hybridization}

Nonradioactive in situ hybridization was performed using digoxigenin (DIG)-labeled cRNA probes transcribed from four different cDNA templates: rat semaphorin(D)III/collapsin-1 cDNA [entire coding region (Giger et al., 1996)], rat neuropilin-1 cDNA [nucleotides 181-2593 of the coding region; a gift from Dr. A. L. Kolodkin, The Johns Hopkins University School of Medicine (Kolodkin et al., 1997)], rat B-50/GAP-43 cDNA [entire coding region; a gift from Dr. L. H. Schrama, Rudolf Magnus Institute for Neurosciences, Utrecht, The Netherlands (Nielander et al., 1987)], and rat CRMP-2 cDNA (nucleotides 1092-1780 of the coding sequence). Briefly, DIG-labeled cRNA probes, messagecomplementary (antisense) or noncomplementary (sense), were generated by in vitro transcription from completely linearized cDNA template, using the appropriate RNA polymerases (T3, T7, SP6; Boehringer Mann- heim, Mannheim, Germany). To enhance tissue penetration and avoid nonspecific background staining, the full-length cRNA probes were alkali-hydrolyzed to an average length of 100-200 bases (SchaerenWiemers and Gerfin-Moser, 1993).

Nonradioactive in situ hybridization was performed as described by Giger et al. (1996), with minor modifications. In short, cryostat sections of $20 \mu \mathrm{m}$ were cut at $-20^{\circ} \mathrm{C}$, thaw-mounted on Superfrost plus slides (Fisher Scientific, Den Bosch, The Netherlands), and post-fixed with $4 \%$ PFA in PBS for $5 \mathrm{~min}$ at room temperature (RT). To enhance tissue penetration and decrease aspecific background staining, sections were reacted with proteinase $\mathrm{K}(10 \mu \mathrm{g} / \mathrm{ml}$; Boehringer Mannheim) in PBS containing $0.1 \%$ Triton $\mathrm{X}-100$ for $10 \mathrm{~min}$, post-fixed for $20 \mathrm{~min}$ in $4 \%$ PFA in PBS, and acetylated with $0.25 \%$ acetic anhydride in $0.1 \mathrm{M}$ triethanolamine for $10 \mathrm{~min}$, all at RT. Subsequently, sections were prehybridized overnight at RT in hybridization buffer $(50 \%$ formamide, $5 \times$ Denhardt's solution, $5 \times$ SSC, $250 \mu \mathrm{g} / \mathrm{ml}$ bakers yeast tRNA, and 500 $\mu \mathrm{g} / \mathrm{ml}$ sheared and heat-denatured herring sperm DNA). Hybridization was performed for $15 \mathrm{hr}$ at $55^{\circ} \mathrm{C}$ (sema III and B-50/GAP-43) or $60^{\circ} \mathrm{C}$ (CRMP-2 and neuropilin-1), using $200 \mathrm{ng} / \mathrm{ml}$ denatured DIG-labeled cRNA probe diluted in hybridization buffer. After hybridization, sections were washed in $5 \times \mathrm{SSC}$ for $5 \mathrm{~min}, 2 \times \mathrm{SSC}$ for $1 \mathrm{~min}, 50 \%$ formamide containing $0.2 \times \mathrm{SSC}$ for $30 \mathrm{~min}$, all at $55^{\circ} \mathrm{C}$ (sema III and B-50/GAP-43) or $60^{\circ} \mathrm{C}$ (CRMP-2 and neuropilin- 1 ), and adjusted to RT in $0.2 \times$ SSC for 5 min. DIG-labeled RNA hybrids were detected with an anti-DIG Fab fragment conjugated to alkaline phosphatase (Boehringer Mannheim)

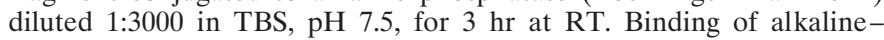
phosphatase-labeled antibody was visualized by incubating the sections

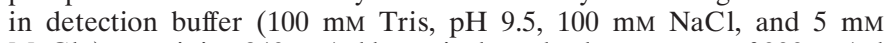
$\mathrm{MgCl}_{2}$ ) containing $240 \mu \mathrm{g} / \mathrm{ml}$ levamisole and color reagents of $300 \mu \mathrm{g} / \mathrm{ml}$ nitro-bluetetrazolium chloride (Sigma, Deisenhofen, Germany) and 170 $\mu \mathrm{g} / \mathrm{ml}$ 5-bromo-4-chloro-3-indolylphosphate (Sigma) for $14 \mathrm{hr}$ at RT.

\section{Neuropilin-1 antibody production}

Anti-neuropilin-1 (AN-1) antibodies were produced as described by Kolodkin et al. (1997). A fragment of rat neuropilin-1, corresponding to amino acids C583-I856, was cloned in the BamHI and HindIII sites of the pQE30 vector (Qiagen, Hilden, Germany), which was subsequently used to produce 6-histidine-tagged neuropilin-1 fragments in Escherichia coli. These proteins were purified on a Ni-NTA-agarose column (Qiagen, Hilden, Germany) according to specifications of the manufacturer. Rabbits were immunized with $\sim 0.5 \mathrm{mg}$ of protein in complete Freund's adjuvant and boosted two times in incomplete Freund's adjuvant. AN-1 antibodies were affinity purified on a neuropilin-1 protein immunosorbent column according to a method described by Oestreicher et al. (1983). In short, neuropilin-1 protein fragments were coupled to $\mathrm{CNBr}$ activated Sepharose 4B in $0.1 \mathrm{M} \mathrm{NaHCO}_{3}$ and $0.5 \mathrm{M} \mathrm{NaCl}, \mathrm{pH} 9.0$, and subsequently washed with $1 \mathrm{M}$ glycine, $\mathrm{pH} 8.0,1 \mathrm{M} \mathrm{NaCl}$ in $0.1 \mathrm{M}$ sodium acetate, $\mathrm{pH} 4.0$, and $0.1 \mathrm{~m}$ sodium borate, $\mathrm{pH}$ 8.5. The Sepharose was packed in a column, and $3 \mathrm{ml}$ of serum was added. The column was washed with PBS, and specifically bound antibodies were eluted with 100 $\mathrm{mm}$ ammonium formate, $\mathrm{pH}$ 2.7. Eluents were neutralized with $1 \mathrm{M}$ ammonia and concentrated by lyophilization.

\section{Immunohistochemistry}

Immunohistochemistry was performed according to standard immunohistochemical procedures incorporating the avidin-biotin-peroxidase complex, using 3,3'-diaminobenzidine tetrachloride (DAB) as a chromophore. In some instances, in situ hybridization was followed by immunohistochemistry. Initially, in situ hybridization was combined with immunofluorescence. Because of the dark purple in situ staining, fluorescent signals were not detectable in double-stained olfactory receptor neurons. Therefore, in subsequent double-labeling experiments, sites of primary antibody binding were visualized with DAB.

Sections were washed in TBS containing $0.2 \%$ Triton X-100 (TBS-T) for $15 \mathrm{~min}$ at RT. B-50/GAP-43 was detected with affinity-purified polyclonal rabbit antibodies derived from antiserum \#9527 [1:1000 dilution; a gift from Dr. L. H. Schrama (Oestreicher et al., 1983)], OMP was detected by polyclonal goat antibodies [antiserum \#255, dilution 1:5000; a gift from Dr. F. L. Margolis, University of Maryland School of Medicine (Keller and Margolis, 1975)], and neuropilin-1 was detected by affinity-purified polyclonal rabbit antibodies from antiserum AN-1 (dilution 1:100). All primary antisera were diluted in TBS-T containing $0.2 \%$ bovine serum albumin (BSA) (Sigma), and sections were incubated in primary antiserum overnight at $4^{\circ} \mathrm{C}$. No immunostaining was detectable in control sections in which the primary antibodies were replaced by 
TBS-T. After three washes in TBS, sections were incubated with biotinylated goat anti-rabbit (1:100; B-50/GAP-43 and neuropilin-1) or biotinylated horse anti-goat (1:100; OMP), all diluted in TBS-T containing $0.2 \% \mathrm{BSA}$, for $1 \mathrm{hr}$ at RT. Then sections were washed three times in TBS and incubated with avidin-biotin-peroxidase complex (Vectastain ABC kit; Vector Laboratories, Burlingame, CA) in TBS containing $0.25 \%$ gelatin and $0.5 \%$ Triton X-100, pH 7.5, for $1 \mathrm{hr}$ at RT. After two washes in TBS and a brief wash in 50 mM Tris- $\mathrm{HCl}, \mathrm{pH} 7.6$, sections were reacted with a solution containing $0.035 \%$ DAB and $0.015 \%$ hydrogen peroxide in Tris- $\mathrm{HCl}, \mathrm{pH} 7.6$, for $15 \mathrm{~min}$ at $\mathrm{RT}$. The reaction was terminated by several washes in Tris-HCl, $\mathrm{pH} 7.6$, and sections were mounted in glycerol.

To confirm the immature phenotype of regenerating olfactory receptor neurons expressing neuropilin-1 or CRMP-2 mRNA, sections probed for neuropilin-1 or CRMP-2 were stained for B-50/GAP-43 or OMP protein. Although OMP-immunoreactivity was clearly visible in neuropilin-1- and CRMP-2 mRNA-expressing olfactory receptor neurons, B-50/GAP-43 protein was hardly detectable in somata of olfactory receptor neurons after the in situ hybridization procedure (data not shown). The lack of double staining might be attributable to the relatively low B-50/GAP-43 protein levels in olfactory receptor somata (Verhaagen et al., 1989; Meiri et al., 1991) or to destruction of the protein during the in situ procedure.

\section{Quantitative analysis}

The number and position of olfactory receptor neurons expressing B-50/ GAP-43, CRMP-2, neuropilin-1 mRNAs, and OMP protein were determined in unoperated age-matched controls and at different time intervals after unilateral bulbectomy or transection of the primary olfactory nerve (see Fig. 7). Sections were analyzed using a digitizer (Calcomp 2000) and a Zeiss microscope (Axioskop) equipped with a $40 \times$ objective and $12.5 \times$ oculars. Per animal, the cells were counted in three stretches $(300 \mu \mathrm{m})$ of septal epithelium, which were $\sim 100 \mu \mathrm{m}$ apart. The relative position of each labeled cell in the neuroepithelium was determined by measuring the ratio between the distance of the cell to the basal lamina and the apical surface at that point. The total number of counted cells at different positions in the epithelium (in pieces of $10 \%$; see Fig. 7) was determined using a frequency analysis program (Quattro Pro 6.01; Novell).

\section{RESULTS}

In this study, the expression patterns of the genes encoding the chemorepellent sema III, neuropilin-1, a sema III receptor, and the intracellular CRMP-2 were examined by nonradioactive in situ hybridization after olfactory bulbectomy or axotomy of the primary olfactory nerve. Their expression profiles were compared with that of established markers for immature (B-50/GAP43) and mature (OMP) olfactory receptor neurons (Farbman and Margolis, 1980; Monti Graziadei et al., 1980; Miragall and Monti Graziadei, 1982; Margolis, 1985; Danciger et al., 1989; Verhaagen et al., 1989, 1990; Meiri et al., 1991; Schwob et al., 1992). The expression of neuropilin-1 was also studied by immunohistochemistry.

The specificity of the in situ hybridization procedure was inferred from the partially overlapping, but clearly distinct, distribution patterns of sema III, neuropilin-1, CRMP-2, and B-50/ GAP-43 mRNA. Sections subjected to the in situ hybridization procedure, but with no probe added, or sections hybridized with sense probe exhibited no hybridization signal.

\section{Expression of neuropilin-1, CRMP-2, and sema III in the intact adult olfactory system \\ Olfactory epithelium}

In adult rats (16 to 18 weeks of age), neuropilin- 1 mRNA and CRMP-2 mRNA were observed in immature B-50/GAP-43positive olfactory receptor neurons, and in a subpopulation of OMP-expressing olfactory receptor neurons located directly above the B-50/GAP-43-positive neurons (Fig. $2 A-D$; see also Figs. $4 A-C, 6 A-D)$. CRMP-2 mRNA expression was relatively abundant in immature olfactory receptor neurons, and expression levels declined gradually in neurons located more superficially (see Figs. $2 B, 4 B, 6 B$ ), whereas the intensity of the signal for neuropilin-1 mRNA was similar in B-50/GAP-43-positive immature and OMP-positive mature neurons (see Figs. $2 A, 4 A, 6 A$ ). Occasionally, patches of olfactory receptor neurons showing strong neuropilin-1 mRNA expression were intermingled with areas of cells displaying much lower hybridization signals (see Figs. $2 A, 4 A, 6 A$ ). Computer-assisted analysis of the distribution of cell bodies expressing neuropilin-1 mRNA, CRMP-2 mRNA, B-50/GAP-43 mRNA, and OMP protein demonstrated that in adult rats neuropilin-1 and CRMP-2 mRNA expression was confined to olfactory receptor neurons in the lower $60 \%$ of the epithelium and corresponds to immature B-50/GAP-43-positive and a subset of mature OMP-positive olfactory receptor neurons located directly adjacent to the cohort of B-50/GAP-43-positive neurons (see Fig. $7 B$ ). In young adult rats ( 7 to 8 weeks of age), the cohort of neuropilin-1- and CRMP-2-positive neurons overlapped predominantly with immature B-50/GAP-43 neurons (see Fig. $7 A$ ). Neuronal perikarya in the olfactory epithelium exhibited no immunoreactivity for neuropilin-1, consistent with previous observations in tadpole (Satoda et al., 1995) and mouse (Kawakami et al., 1996). Neuropilin-1 protein was detected in fascicles of primary olfactory axons traversing the lamina propria.

In situ hybridization on transverse sections along the entire rostrocaudal axis of the olfactory epithelium revealed that neuropilin-1 mRNA and CRMP-2 mRNA were present throughout the entire olfactory epithelium. Olfactory receptor neurons in the septum and in all turbinates displayed neuropilin-1 and CRMP-2 mRNA expression (Fig. $3 A, B$ ). Sema III hybridization signals were not observed in the olfactory epithelium nor in other cellular compartments of the olfactory turbinates of adult rats (data not shown).

\section{Olfactory bulb}

Strong-to-moderate in situ hybridization signals for sema III were present in the mitral and tufted cells, as shown previously (Giger et al., 1998). Moderate-to-weak signals were observed in subsets of periglomerular cells (Fig. $4 G$ ). Pial cells covering the olfactory bulb and lining the caudal surface of the cribriform plate were strongly labeled in young adult and adult rats (Fig. $4 G$ ). Immunolabeling of transversal and horizontal sections of adult rat main olfactory bulb revealed that neuropilin-1-positive olfactory axons entered the olfactory nerve layer by passing through sema IIInegative channels in the cribriform plate (Fig. 4G). Neuropilin1-positive axons terminated in the glomeruli of the olfactory bulb (Figs. 3C, 4G). Neuropilin-1 immunoreactivity was confined to the rostrolateral and caudal glomeruli of the main olfactory bulb. Moderate neuropilin-1 immunoreactivity was observed in most glomeruli, whereas a small number of glomeruli was either very strongly labeled or unlabeled (Fig. $3 C$ ). The most rostral glomeruli and glomeruli in the dorsal and ventral extent of the olfactory bulb lacked neuropilin-1 labeling (Fig. 3C). As expected, OMP protein was detected in all glomeruli (Fig. 3D).

\section{Expression of neuropilin-1, CRMP-2, and sema III after unilateral bulbectomy}

Olfactory epithelium

The changes in the expression of neuropilin-1 mRNA and CRMP-2 mRNA after unilateral bulbectomy are illustrated in Figures 2, 4, and 7. On the contralateral control side, both messengers were expressed in the lower compartment of the epithelium. This expression pattern was indistinguishable from 
Neuropilin-1

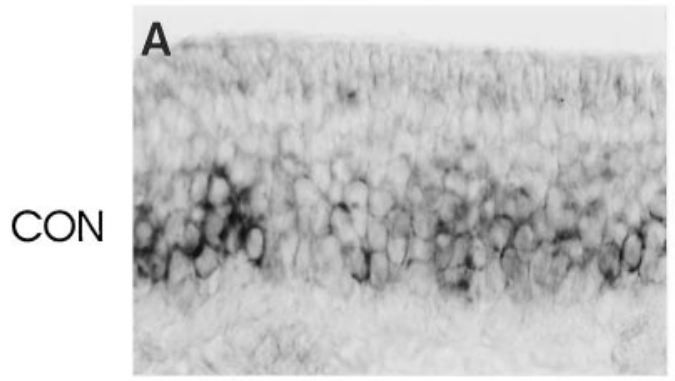

E

$3 d$
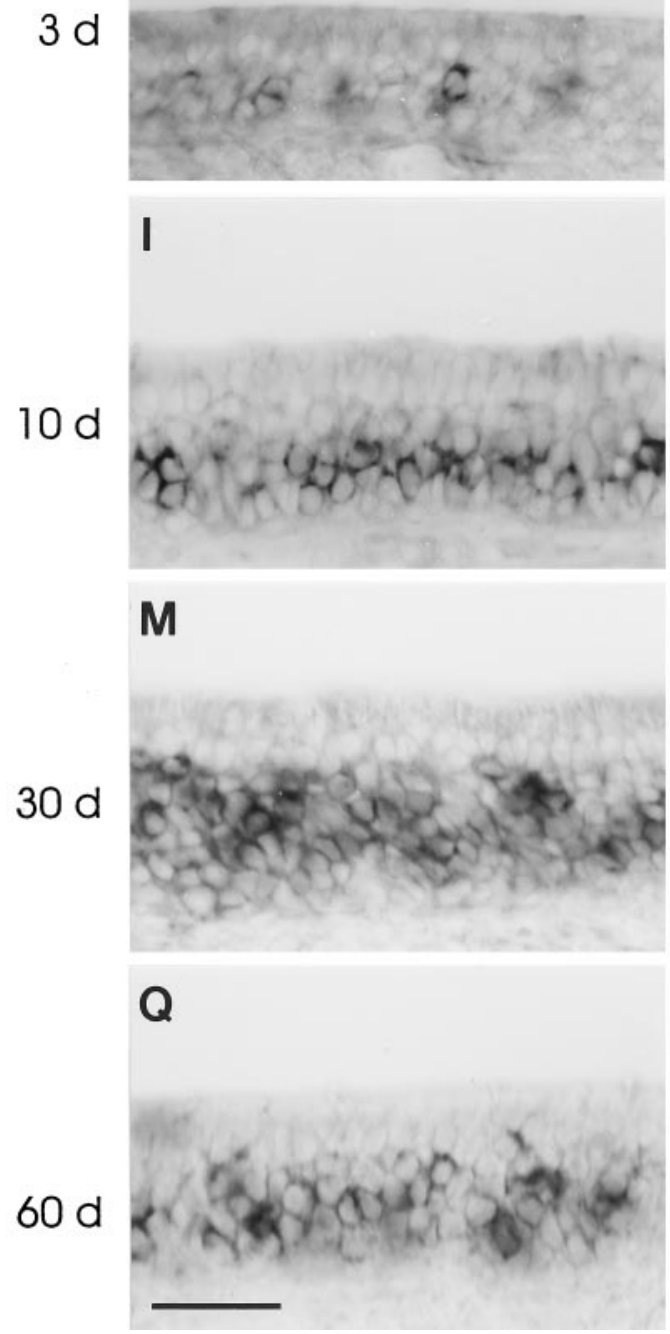

CRMP-2

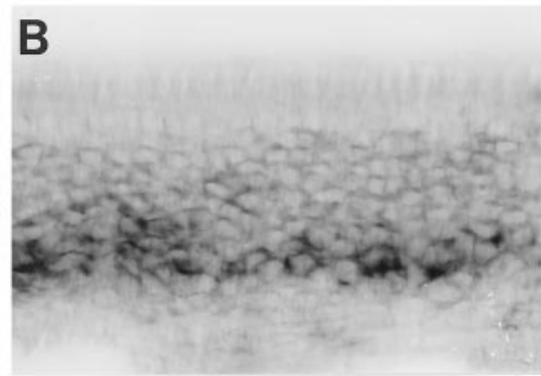

F
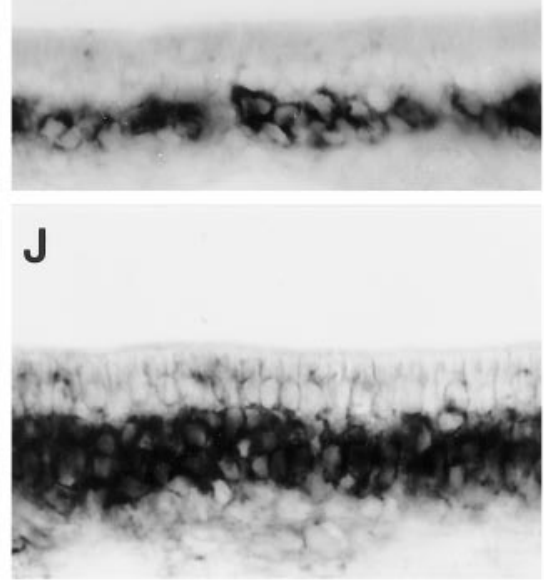

N

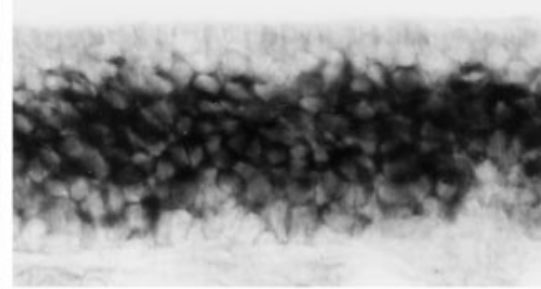

R

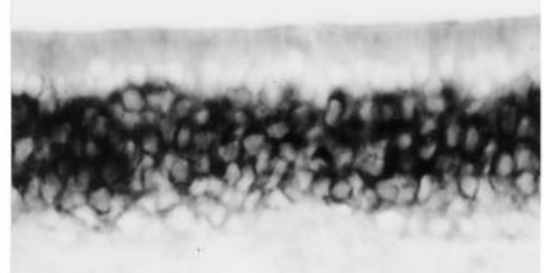

B-50/GAP-43

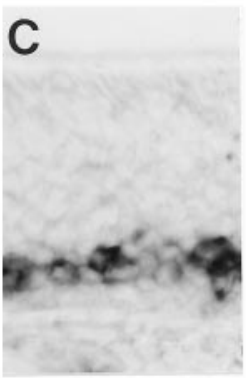

G
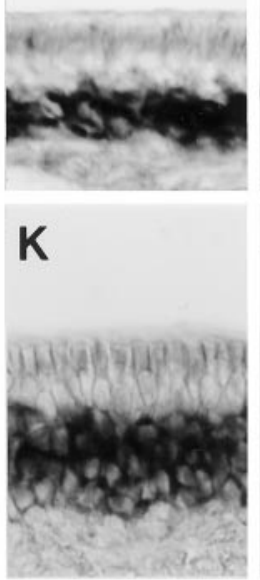

0

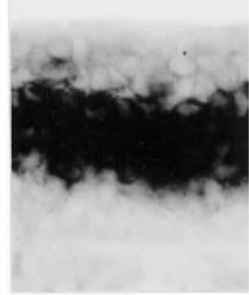

S

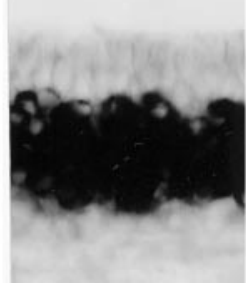

OMP

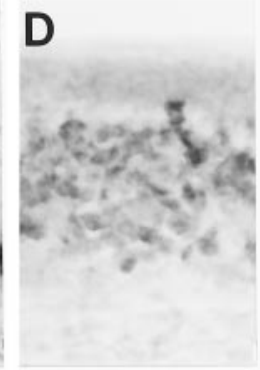

H
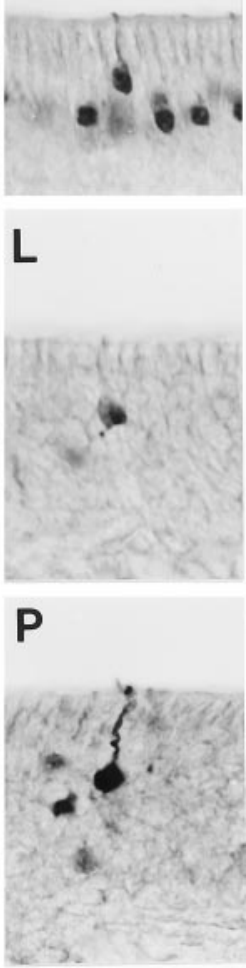

T

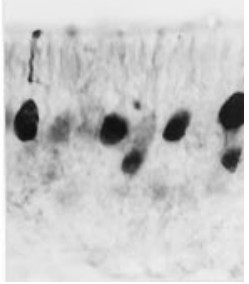

Figure 2. Olfactory receptor neurons formed after bulbectomy express neuropilin-1 and CRMP-2 mRNA. Rats subjected to unilateral bulbectomy were allowed to recover for $3(E-H), 10(I-L), 30(M-P)$, and $60(Q-T)$ d. Horizontal cryosections of septal olfactory epithelium from unlesioned animals $(C O N, 16$ weeks of age) and bulbectomized animals were subjected to in situ hybridization for neuropilin-1 mRNA $(A, E, I, M, Q)$, CRMP-2 mRNA $(B$, $F, J, N, R)$, B-50/GAP-43 mRNA $(C, G, K, O, S)$, and immunohistochemistry for OMP protein $(D, H, L, P, T)$. In control epithelium, neuropilin-1 mRNA $(A)$ and CRMP-2 mRNA $(B)$ are expressed in olfactory receptor neurons in the lower region of the olfactory epithelium, corresponding to immature B-50/GAP-43 mRNA-expressing neurons $(C)$ and to a subset of mature OMP-positive neurons directly adjacent to the immature neurons $(D)$. Note that neuropilin-1 and CRMP-2 signals are absent from sustentacular cells and stem cells. As a result of bulbectomy, massive loss of mature OMP-expressing olfactory receptor neurons has occurred. A few OMP-positive neurons remain scattered throughout the ipsilateral epithelium $(H, L, P, T)$. The vast majority of neurons in the bulbectomized epithelium are immature B-50/GAP-43-positive $(G, K, O, S)$. After bulbectomy, neuropilin-1 $(E, I, M, Q)$ and CRMP-2 $(F, J, N, R)$ mRNA expression overlaps with the cohort of immature B-50/GAP-43-expressing neurons. The bulbectomy-induced changes in the mRNA expression for neuropilin-1 and CRMP-2 persist up to at least $60 \mathrm{~d}$ after lesion $(Q, R)$. Scale bar, $55 \mu \mathrm{m}$. 


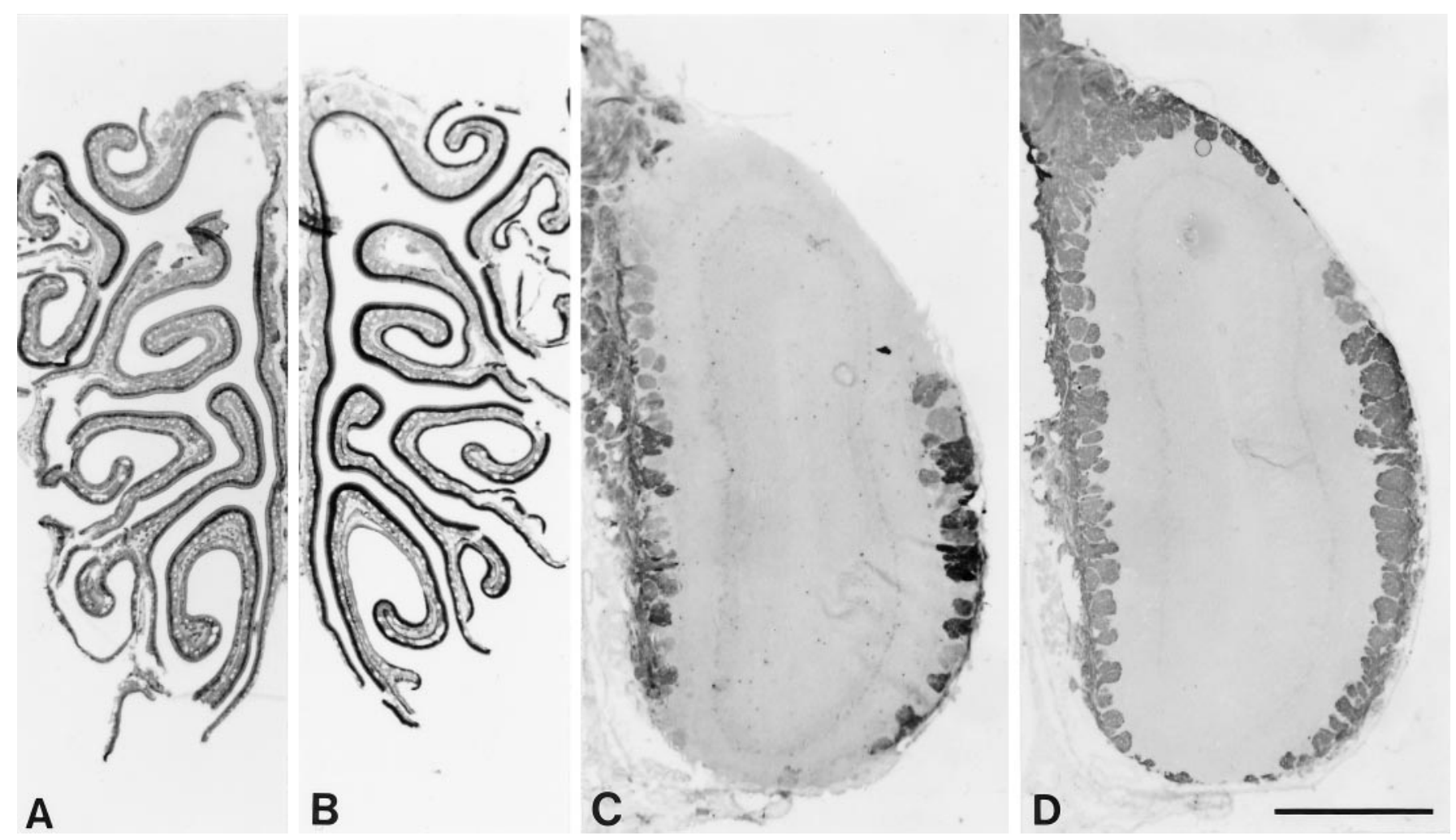

Figure 3. Low-magnification overviews of the expression of neuropilin-1 and CRMP-2 in the primary olfactory system. Low-power photomicrographs of consecutive coronal sections of the olfactory epithelium $(A, B)$ and main olfactory bulb $(C, D)$. Sections of the adult rat olfactory system were analyzed using in situ hybridization for neuropilin-1 $(A)$ and CRMP-2 $(B)$ or immunohistochemistry for neuropilin-1 $(C)$ and OMP $(D)$. Note that hybridization signals for neuropilin-1 and CRMP-2 are present throughout the dorsoventral extent of the epithelium $(A, B)$. At the level of the olfactory bulb, however, neuropilin-1 immunoreactivity is absent from glomeruli at the dorsal and ventral boundaries of the olfactory bulb $(C)$, whereas OMP labels all glomeruli (D). Scale bar (in $D$ ): $A, B, 2 \mathrm{~mm} ; C, D, 900 \mu \mathrm{m}$.

that of unlesioned control rats (see Fig. 7, compare $B, G$ ). Three days after bulbectomy, the thickness of the epithelium at the lesioned side was reduced substantially, and the OMP-positive mature olfactory neurons had almost completely disappeared (Fig. 2E-H). As has been observed previously, the intensity of OMP immunoreactivity in the few remaining OMP-positive ipsilateral mature olfactory receptor neurons appeared greater than in neurons on the unoperated side (Monti Graziadei, 1983; Verhaagen et al., 1990; Carr et al., 1998). In the thin remaining layer of olfactory epithelium, moderate neuropilin-1 and CRMP-2 mRNA expression was evident (Fig. $2 E, F$ ). At 10 and $30 \mathrm{~d}$ after lesion, the thickness of the epithelium had increased as a result of the formation of new olfactory receptor neurons. Most of these neurons displayed an immature phenotype (B-50/GAP-43positive-OMP-negative) and expressed high levels of neuropilin-1 and CRMP-2 mRNA (see Figs. $2 I-P, 7 C$ ). At $60 \mathrm{~d}$ after lesion, the thickness of the epithelium on the lesioned side had somewhat decreased compared with 10 and $30 \mathrm{~d}$ after lesion, but neuropilin-1 and CRMP-2 mRNA continued to be expressed throughout the population of immature olfactory neurons (see Figs. $2 Q-T, 7 D)$. The phenotype of neuropilin-1- and CRMP-2positive regenerating olfactory receptor neurons was confirmed by immunolabeling sections probed for neuropilin-1 mRNA or CRMP-2 mRNA with OMP antibodies. This experiment showed that only a small number of regenerating olfactory receptor neurons expressed both neuropilin-1 mRNA or CRMP-2 mRNA and OMP protein (Fig. 4D-F). Quantitative analysis showed an increase in the relative number of neuropilin-1 mRNA- or
CRMP-2 mRNA-expressing olfactory receptor neurons at $10 \mathrm{~d}$ after bulbectomy compared with control epithelium (see Fig. $7 A, C)$. At $60 \mathrm{~d}$ after lesion, the number of olfactory neurons expressing the messengers for neuropilin-1 or CRMP-2 had slightly decreased compared with $10 \mathrm{~d}$ but was still higher than the number of olfactory receptor neurons expressing neuropilin-1 or CRMP-2 in control epithelium (see Fig. $7 B, D$ ). At both 10 and $60 \mathrm{~d}$ after bulbectomy, cohorts of neuropilin-1 mRNA- and CRMP-2 mRNA-expressing neurons displayed almost complete overlap with the B-50/GAP-43 mRNA-containing neurons, thereby corroborating the qualitative histological observations (see Fig. 7C,D).

At none of the postlesion time intervals was sema III mRNA expression observed in either the ipsilateral or contralateral olfactory epithelium (data not shown).

\section{Olfactory bulb}

After olfactory bulbectomy, a heterogeneous cellular scar developed, occupying the entire bulbar cavity. At 10, 30, and $60 \mathrm{~d}$ after lesion, prominent expression of sema III mRNA was present in an increasing number of small non-neuronal cells of the scar (Figs. $4 H, J, 5 B, C)$. Strings and patches of sema III mRNA-containing cells continuous with the pial sheet covered the caudal surface of the cribriform plate. To examine the relationship between sema III-positive cells and regenerating olfactory axons in the scar, in situ hybridization for sema III was combined with immunohistochemistry for neuropilin-1 or B-50/GAP-43. In the unlesioned contralateral olfactory bulb, neuropilin-1 and B-50/GAP-43 ex- 

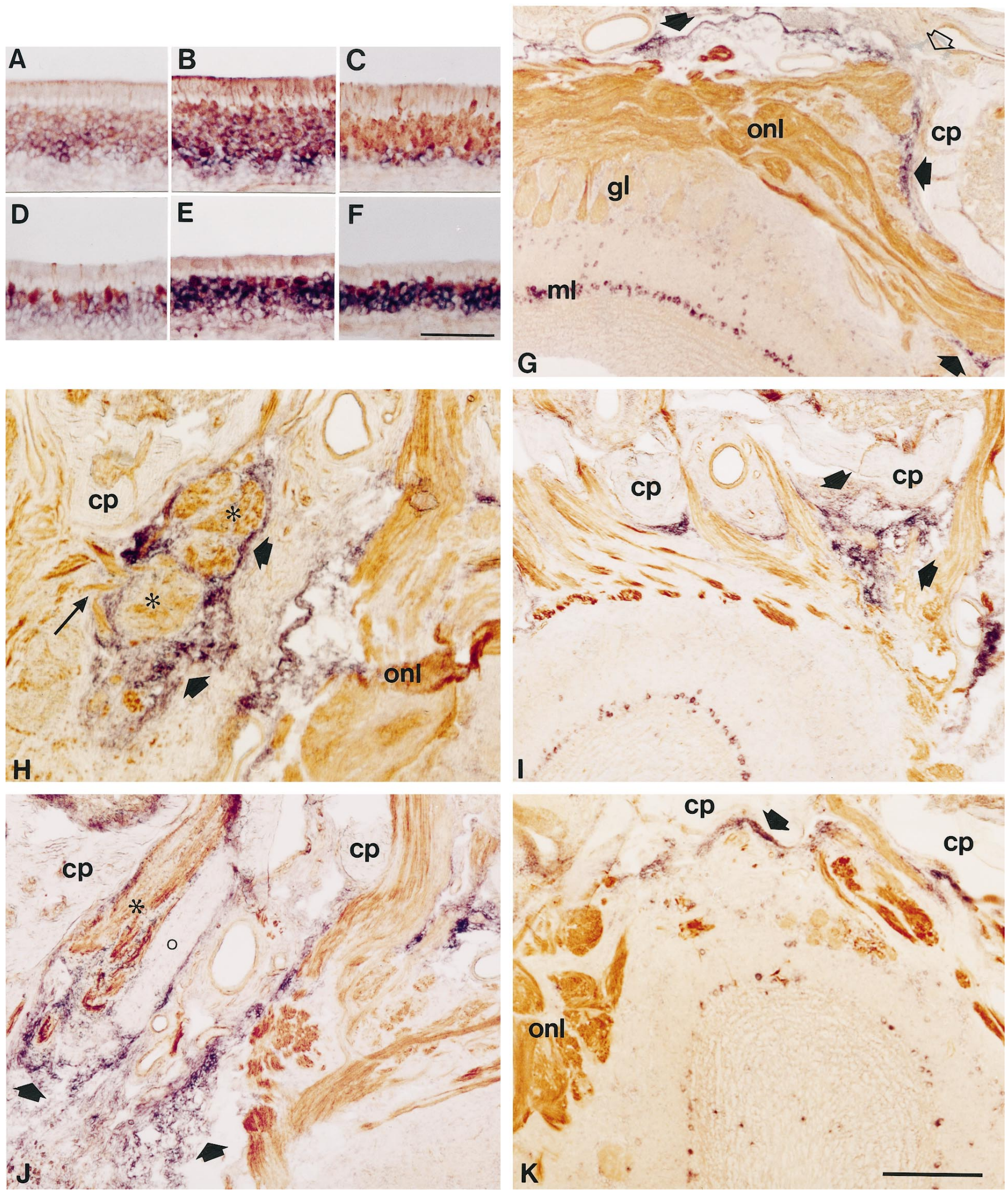

Figure 4. A-F, Double labeling combining in situ hybridization and immunohistochemistry to examine the expression of neuropilin-1 mRNA and CRMP-2 mRNA in OMP-positive neurons in the intact olfactory epithelium and after bulbectomy. Horizontal sections of olfactory epithelium of unlesioned animals ( 18 weeks of age) and bulbectomized animals ( $60 \mathrm{~d}$ after lesion) were double stained for neuropilin-1 mRNA ( $A, D$ ), CRMP-2 mRNA $(B, E)$, or B-50/GAP-43 mRNA $(C, F$, purple) and OMP protein (brown). Sections probed for neuropilin-1 mRNA were only briefly stained for OMP to allow detection of double-stained profiles. Note that in control epithelium a subset of OMP-expressing mature neurons contains neuropilin-1 and CRMP-2 mRNA $(A-C)$, whereas after bulbectomy, only a small number of neurons express both OMP and (Figure legend continues) 
pression resembled control. At 3 and $6 \mathrm{~d}$ after bulbectomy, no regenerating B-50/GAP-43- or neuropilin-1-positive fibers were visible in the bulbar cavity, suggesting that regenerating olfactory axons had not yet reached the lesion site. At 10 d, neuropilin-1and B-50/GAP-43-immunoreactive axons were observed directly adjacent to the cribriform plate and penetrated the rostral part of the bulbar cavity. Regenerating olfactory receptor neurons elaborated axons into the bulbar cavity, avoiding the sema IIIexpressing cells. In addition, some fascicles of regenerating olfactory axons were surrounded by patches and strings of sema III-positive cells (Fig. 4H). At 30 and $60 \mathrm{~d}$ after bulbectomy, a progressive increase was observed in the number of sema IIIpositive cells. The bulbar cavity was entirely filled with scar tissue containing multiple strings and patches of tightly packed sema III-positive cells encapsulating the regenerating neuropilin-1- and B-50/GAP-43-immunoreactive nerve bundles, apparently preventing these fibers from extending further into the bulbar cavity (Figs. $4 J, 5 B, C$ ). In addition to multiple neuropilin-1-positive nerve bundles, we observed a single encapsulated B-50/GAP-43 fiber bundle that was neuropilin-1-negative in all animals examined (Fig. 4J). This neuropilin-1-negative axon bundle might have arisen from olfactory receptor neurons of the vomeronasal epithelium, because these neurons do not express neuropilin-1 (Satoda et al., 1995).

\section{Expression of neuropilin-1, CRMP-2, and sema III after transection of the primary olfactory nerve Olfactory epithelium}

The changes in the expression of neuropilin-1 mRNA and CRMP-2 mRNA after transection of the primary olfactory nerve are illustrated in Figures 6 and 7. As observed after olfactory bulbectomy, transection of the primary olfactory nerve resulted in a pronounced loss of mature OMP-positive olfactory receptor neurons and an induction in the formation of new immature B-50/GAP-43-positive neurons. At 10 and $30 \mathrm{~d}$ after transection, neuropilin-1 mRNA and CRMP-2 mRNA were present in a more or less continuous band of immature cells (Fig. $6 E-H$ ). This response was similar to that observed at 10 and $30 \mathrm{~d}$ after bulbectomy (for a quantitative comparison, see Fig. 7C,E). At $60 \mathrm{~d}$ after transection, expression for neuropilin-1 and CRMP-2 resembled control expression patterns (Fig. 6, compare $A, B$, to $I, J)$, i.e., olfactory receptor neurons in the lower compartment of the olfactory epithelium expressed neuropilin-1 mRNA, whereas CRMP-2 mRNA was expressed in a basal-to-apical gradient (Fig. $6 I, J)$. Consistent with the histological observations, quantitative measurements showed that the distribution and relative numbers of neurons expressing neuropilin-1 and CRMP-2 mRNA at $60 \mathrm{~d}$ after lesion were very similar to control. Noticeably, a somewhat larger cohort of OMP-expressing cells was detected at $60 \mathrm{~d}$ after axotomy compared with age-matched control (Fig. 7B, F).

\section{Olfactory bulb}

At 3 and $6 \mathrm{~d}$ after olfactory nerve transection, the olfactory bulb was almost devoid of neuropilin-1 and B-50/GAP-43 immunoreactivity. Nerve bundles in the lamina propria had shrunken and contained neuropilin-1- and B-50/GAP-43-immunoreactive debris (data not shown). By $10 \mathrm{~d}$, when the first olfactory axons had traversed the cribriform plate and started to reinnervate the olfactory bulb, regenerating olfactory axons were positive for neuropilin-1 and B-50/GAP-43 (data not shown) (Figs. 4I, 5A). The relatively small lesion site contained sema III-positive cells arranged in typical strings between the cribriform plate and the olfactory bulb. Neuropilin-1- and B-50/GAP-43-immunoreactive axons were lined by these strings of sema III-positive cells, which accompanied them through the lesion site into undamaged regions of the olfactory bulb (Figs. $4 I, 5 A$ ). In contrast to the progressive increase of sema III-positive cells after olfactory bulbectomy, sema III-positive cells had primarily disappeared at 30 and $60 \mathrm{~d}$ after transection of the olfactory nerve, and nonneuronal sema III mRNA expression was restricted to cells at the caudal surface of the cribriform plate, reminiscent of expression in control uninjured bulb (Fig. $4 K$ ). Expression of sema III mRNA in neurons of the olfactory bulb was unchanged after axotomy (data not shown). Expression patterns for neuropilin-1 and B-50/GAP-43 in the main olfactory bulb had returned to control, except for some ectopic glomerular innervation in the rostral olfactory bulb (Fig. $4 K$ ).

\section{DISCUSSION}

The present results indicate that the expression patterns of semaphorin III, neuropilin-1, and CRMP-2 are spatially and temporally regulated during regeneration of the primary olfactory pathway. In addition to previous studies exploring the role of growth-promoting factors during regeneration of the olfactory nerve (Liesi, 1985; Doucette, 1996), the current observations provide evidence for chemorepulsive control of primary olfactory nerve regeneration. In intact olfactory bulb, the ligand for neuropilin-1, sema III, was expressed by non-neuronal cells at the caudal surface of the cribriform plate by pial cells covering the lateral and medial aspect of the bulb and by second-order neurons in the olfactory bulb, all in close proximity to neuropilin-1positive olfactory axons (Fig. 8). After olfactory bulbectomy or axotomy of the olfactory nerve, a recapitulation of developmental patterns of neuropilin-1 and CRMP-2 mRNA expression was

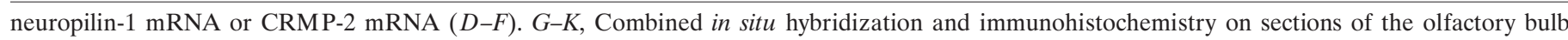

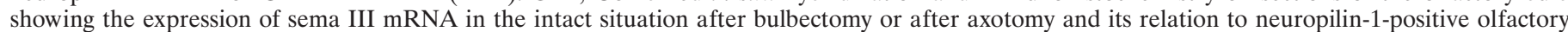

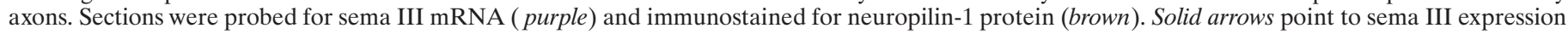

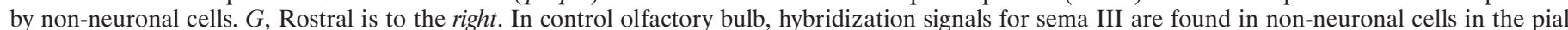

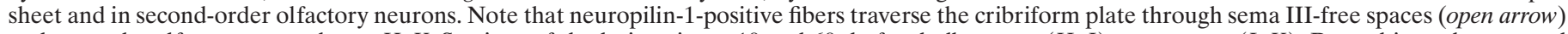

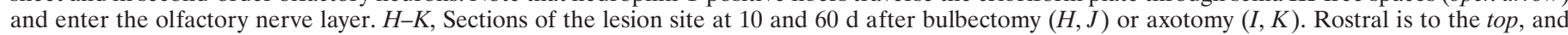

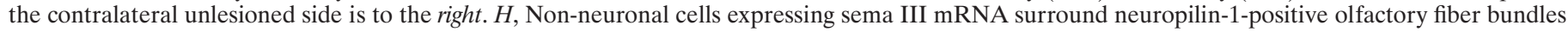

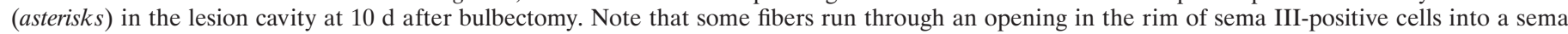

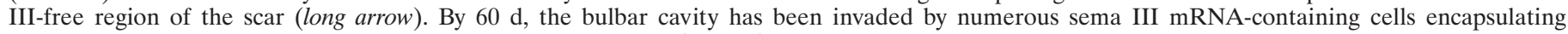

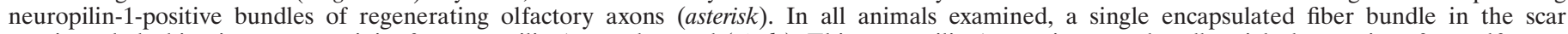

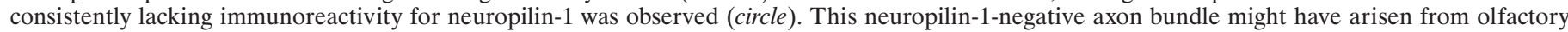

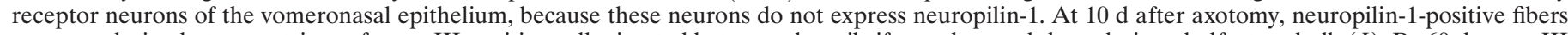

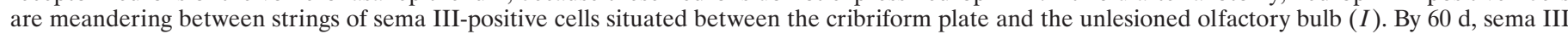

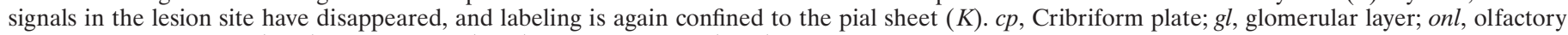
nerve layer. Scale bars: (in $F$ ) $A-F, 95 \mu \mathrm{m}$; (in $K$ ) $I, J, K, 300 \mu \mathrm{m}$; (in $K$ ) $H, 125 \mu \mathrm{m}$. 

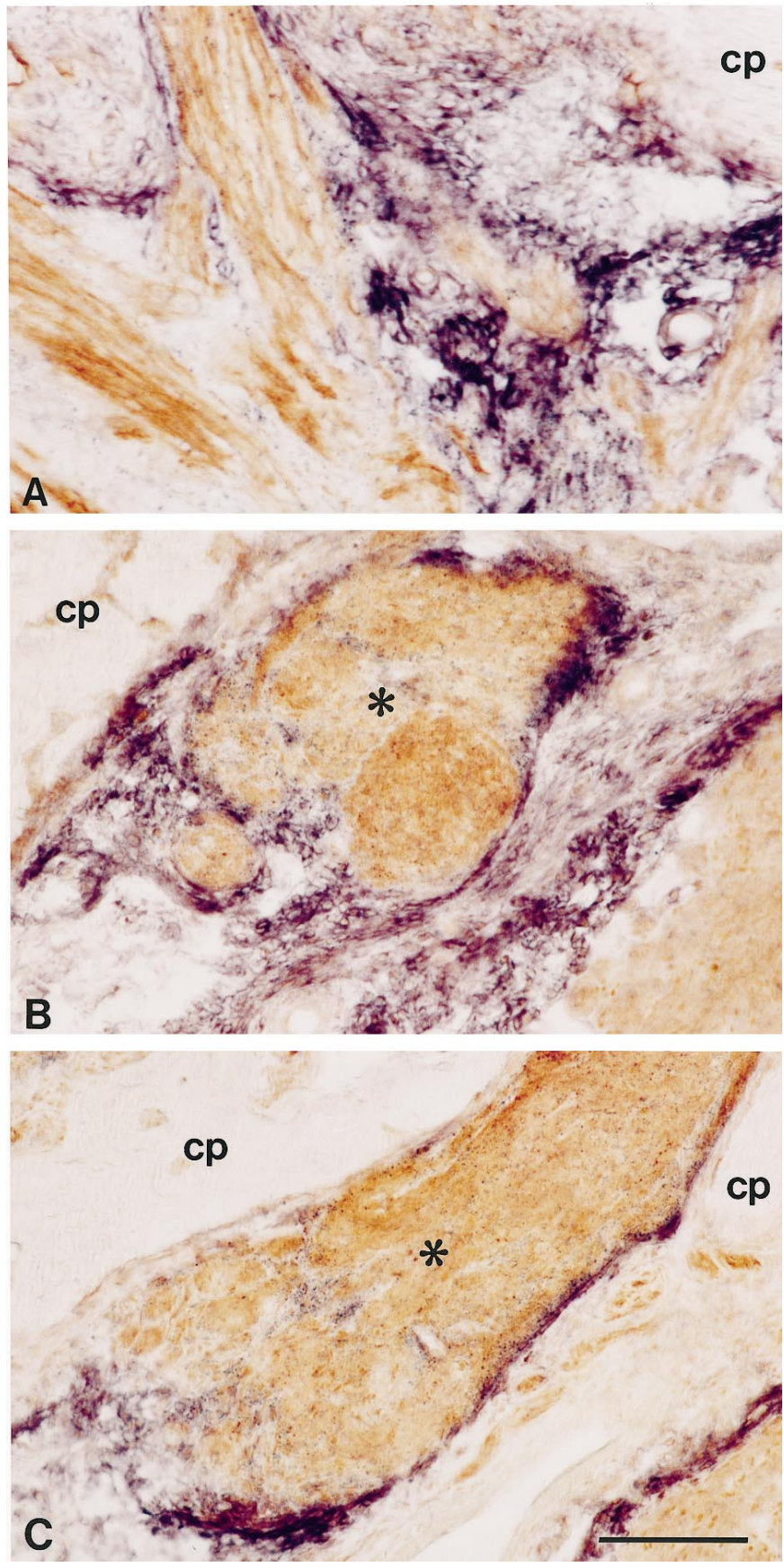

Figure 5. Relationship between regenerating bundles of olfactory axons and sema III mRNA expression in the injured olfactory system. Highpower photomicrographs showing horizontal sections of the lesion site at $10 \mathrm{~d}$ after transection of the primary olfactory nerve $(A)$ or $60 \mathrm{~d}$ after bulbectomy $(B, C)$. Sections were probed for sema III mRNA (purple) and immunolabeled subsequently for neuropilin-1 $(A)$ or B-50/GAP-43 protein $(B, C$, brown $)$. At $10 \mathrm{~d}$ after axotomy, neuropilin-1-positive olfactory axons grow through sema III-free channels lined by strings of sema III mRNA-expressing cells. These cells are continuous with the pial sheet and cover the cribriform plate $(A)$. At $60 \mathrm{~d}$ after bulbectomy, bundles of regenerating olfactory axons (asterisks) are tightly encapsulated by sema III-positive cells $(B, C)$. Scale bar, $170 \mu \mathrm{m}$.

observed. Bulbectomy induced extensive scar formation accompanied by the appearance of numerous sema III mRNAcontaining non-neuronal cells encapsulating bundles of neuropilin-1-immunoreactive fibers, apparently arresting their extension into deeper portions of the bulbar cavity (Fig. 8). In contrast, after axotomy, transient sema III expression occurs in strings and patches of cells lining neuropilin-1-immunoreactive olfactory axons, which appeared to grow uninhibited through sema III-free spaces to the intact nerve layer. Our results demonstrate, to our knowledge for the first time, that injury to the CNS induces robust expression of a chemorepulsive semaphorin, i.e., sema III, in the glial scar.

\section{Neuropilin-1 and CRMP-2 define a subpopulation of olfactory receptor neurons}

During development of the primary olfactory system, combinatorial actions of cell adhesion molecules, ECM proteins, and odorant receptors are governing the establishment of the highly organized connections between the olfactory epithelium and the main olfactory bulb (Miragall et al., 1989; Doucette, 1990, 1996; Chung et al., 1991; Miragall and Dermietzel, 1992; Ressler et al., 1993; Vassar et al., 1993; Krull et al., 1994; Strottmann et al., 1994; Gong and Shipley, 1995, 1996; Mombaerts et al., 1996; Treloar et al., 1996; Whitesides and LaMantia, 1996; Yoshihara et al., 1997; Julliard and Hartmann, 1998). Recently, patterning of developing olfactory axons has been suggested to involve chemorepellents and their receptors (Giger et al., 1996; Sheperd et al., 1996; Zhang et al., 1996; Kobayashi et al., 1997; Livesey and Hunt, 1997; Williams-Hogarth et al., 1997; Yoshida et al., 1997). Collapsin-1, the chicken homolog of sema III (Luo et al., 1993; Koppel et al., 1997), induces growth cone collapse of cultured embryonic olfactory receptor neurons (Kobayashi et al., 1997), which express neuropilin-1 (Takagi et al., 1991) and CRMP-2, proteins required for sema III-induced growth cone collapse (Goshima et al., 1995; Wang and Strittmatter, 1996; Feiner et al., 1997; He and Tessier-Lavigne, 1997; Kolodkin et al., 1997; Kamata et al., 1998). The sensitivity of olfactory receptor neurons to sema III and the spatiotemporal expression patterns of sema III, neuropilin-1, and CRMP-2 suggest that sema III-neuropilin-1 signaling contributes to the guidance and target finding of developing primary olfactory axons.

In the adult olfactory neuroepithelium, neuropilin-1 and CRMP-2 are expressed in differentiating B-50/GAP-43-positive neurons and in a subset of OMP-positive neurons directly adjacent to the differentiating neurons. Maturation of olfactory receptor neurons is accompanied by a decline in the expression of B-50/GAP-43 and an induction of OMP. This switch in gene expression coincides with the cessation of axonal growth and the formation of synapses in the glomeruli of the olfactory bulb (Farbman and Margolis, 1980; Miragall and Monti Graziadei, 1982; Danciger et al., 1989; Verhaagen et al., 1989; Schwob et al., 1992). The topography of neuropilin-1- and CRMP-2-positive cell bodies in the olfactory epithelium suggests that the sema III receptor and CRMP-2 are expressed in immature olfactory receptor neurons, elaborating axons into the bulb, as well as in young mature neurons that are establishing connections on target cells in the bulb. Sema III may affect the ongoing ingrowth of neuropilin-1-positive olfactory axons at at least three sites in the intact adult olfactory bulb. First, as neuropilin-1-positive primary olfactory axons traverse through holes in the cribriform plate, sema III secreted from cells at the caudal surface of the cribriform plate may form a chemorepulsive gradient, instructing them to deflect from the cribriform plate into the deeper portion of the olfactory nerve layer. Second, expression of sema III in more caudal regions of the pial sheet indicates that sema III may subserve a function in preventing olfactory axons from innervat- 
Neuropilin-1
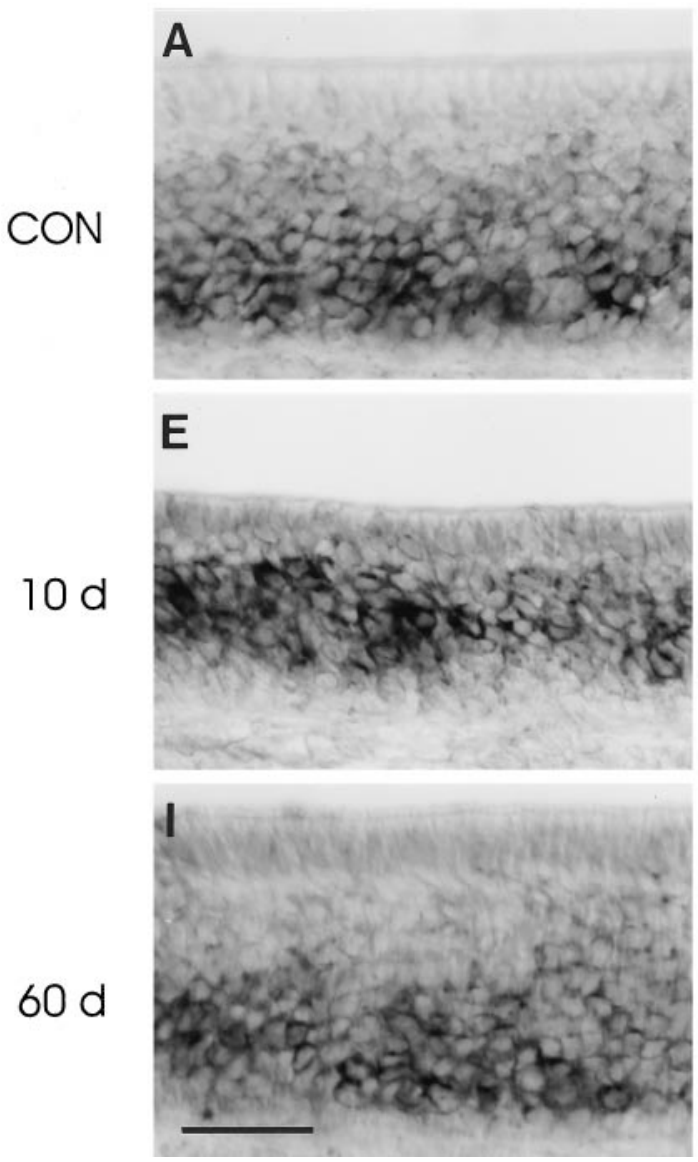

CRMP-2

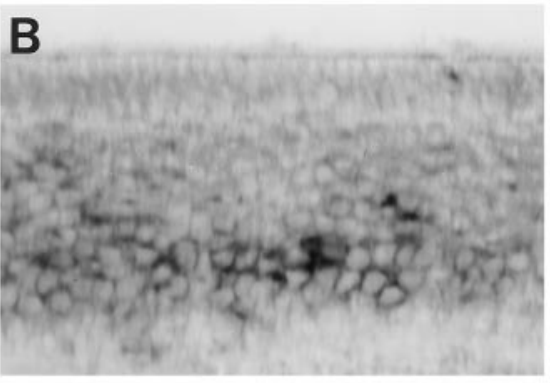

F
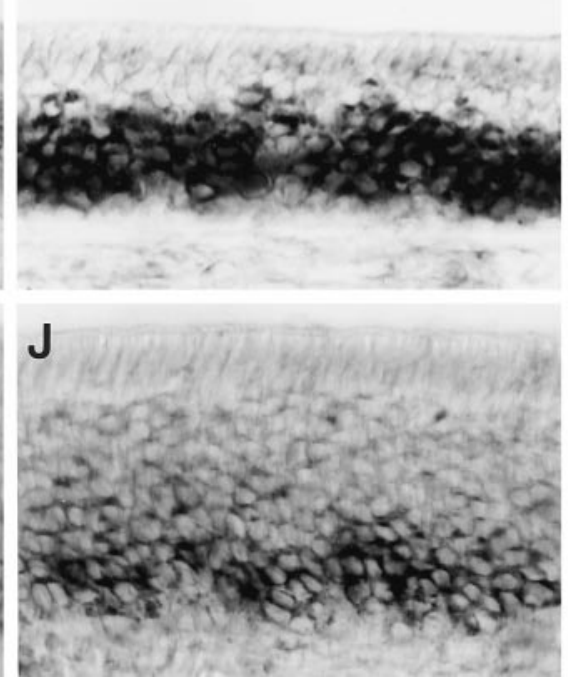

B-50/GAP-43
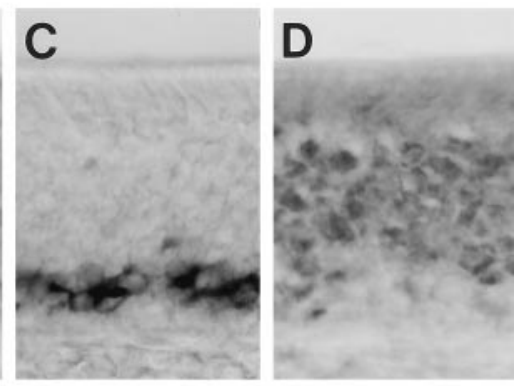

G

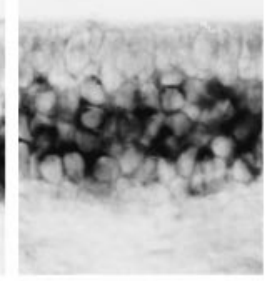

H

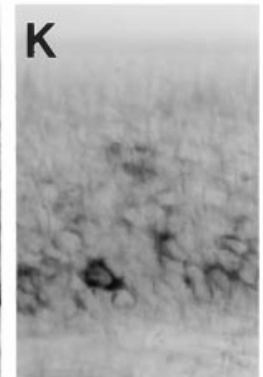

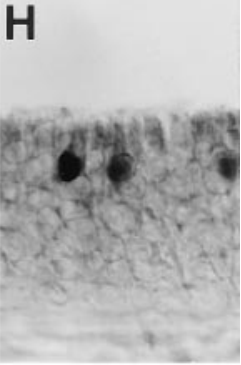

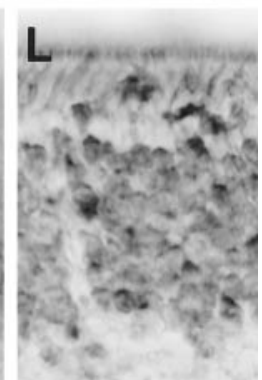

Figure 6. Neuropilin-1 and CRMP-2 mRNA expression returns to control during reconstitution of the olfactory epithelium after axotomy. Rats subjected to primary olfactory nerve transection were allowed to recover for $10(E-H)$ and $60(I-L)$ d. Horizontal cryosections of olfactory epithelium from unlesioned animals $(C O N, 16$ weeks of age) and axotomized animals were subjected to in situ hybridization for neuropilin-1 mRNA $(A, E, I)$, CRMP-2 mRNA $(B, F, J)$, B-50/GAP-43 mRNA $(C, G, K)$, and immunohistochemistry for OMP protein $(D, H, L)$. In control animals, neuropilin-1 and CRMP-2 mRNA-containing olfactory receptor neurons correspond to cohorts of both immature B-50/GAP-43-positive and mature OMP-positive neurons in the lower compartment of the epithelium $(A-D)$. At $10 \mathrm{~d}$ after axotomy, abundant mRNA expression for neuropilin-1 and CRMP-2 is confined to immature B-50/GAP-43 neurons occupying most of the epithelium $(E-H)$. The expression patterns for neuropilin-1 and CRMP-2 are reminiscent of those seen at $10 \mathrm{~d}$ after bulbectomy (Fig. $2 I-L$ ). By $60 \mathrm{~d}$ after lesion, B-50/GAP-43 and OMP expression are very similar to control patterns $(K, L)$. At this postlesion time interval, neuropilin-1- and CRMP-2 mRNA-positive neurons are again confined to the lower region of the epithelium $(I, J)$. Scale bar, $55 \mu \mathrm{m}$.

ing the contralateral bulb, thereby maintaining the strictly unilateral projection of the primary olfactory nerve bundles (Farbman, 1992; Shipley and Ennis, 1996). Finally, as olfactory fibers arrive in the olfactory glomeruli, they cease growing and form synapses on second-order neurons (Sheperd, 1972; Farbman, 1992; Shipley and Ennis, 1996). Continued expression of neuropilin-1 in axons entering the glomeruli and the presence of its ligand sema III in periglomerular, mitral, and tufted cells invites the speculation that target-derived sema III serves as a signal inhibiting further extension of axon endings into the deeper layers of the bulb. Interestingly, recent findings show that morphological plasticity of synaptic boutons is dependent on the relative balance between attractive and repulsive factors (Winberg et al., 1998). Disturbance of the balance between growth-promoting and growthinhibiting forces by ectopic expression of the growth-associated protein B-50/GAP-43 in mature olfactory receptor neurons resulted in aberrant olfactory axon endings and some ectopic primary olfactory projections into deeper layers of the olfactory bulb
(Holtmaat et al., 1995, 1997). In future studies, genetic manipulation of sema III levels in vivo will be important to further elucidate the role of this chemorepellent in plasticity of the mature olfactory system.

Olfactory receptor neurons throughout the rostrocaudal and dorsoventral extent of the neuroepithelium express neuropilin-1 mRNA, whereas in the bulb, neuropilin-1 immunoreactivity is confined to the rostrolateral and caudal glomeruli. Thus, expression of neuropilin-1 in the primary olfactory system does not show the restricted spatial projection observed for odorant receptor and ECM proteins (Buck and Axel, 1991; Ressler et al., 1993; Vassar et al., 1993; Strottmann et al., 1994; Mombaerts et al., 1996; Yoshihara et al., 1997). This is consistent with observations in the tadpole (Satoda et al., 1995). Interestingly, in the tadpole, primary olfactory axons containing no or low levels of neuropilin-1 express another transmembrane protein, plexin (Ohta et al., 1995; Satoda et al., 1995). The identification of one of the plexins as a semaphorin receptor in the immune system 

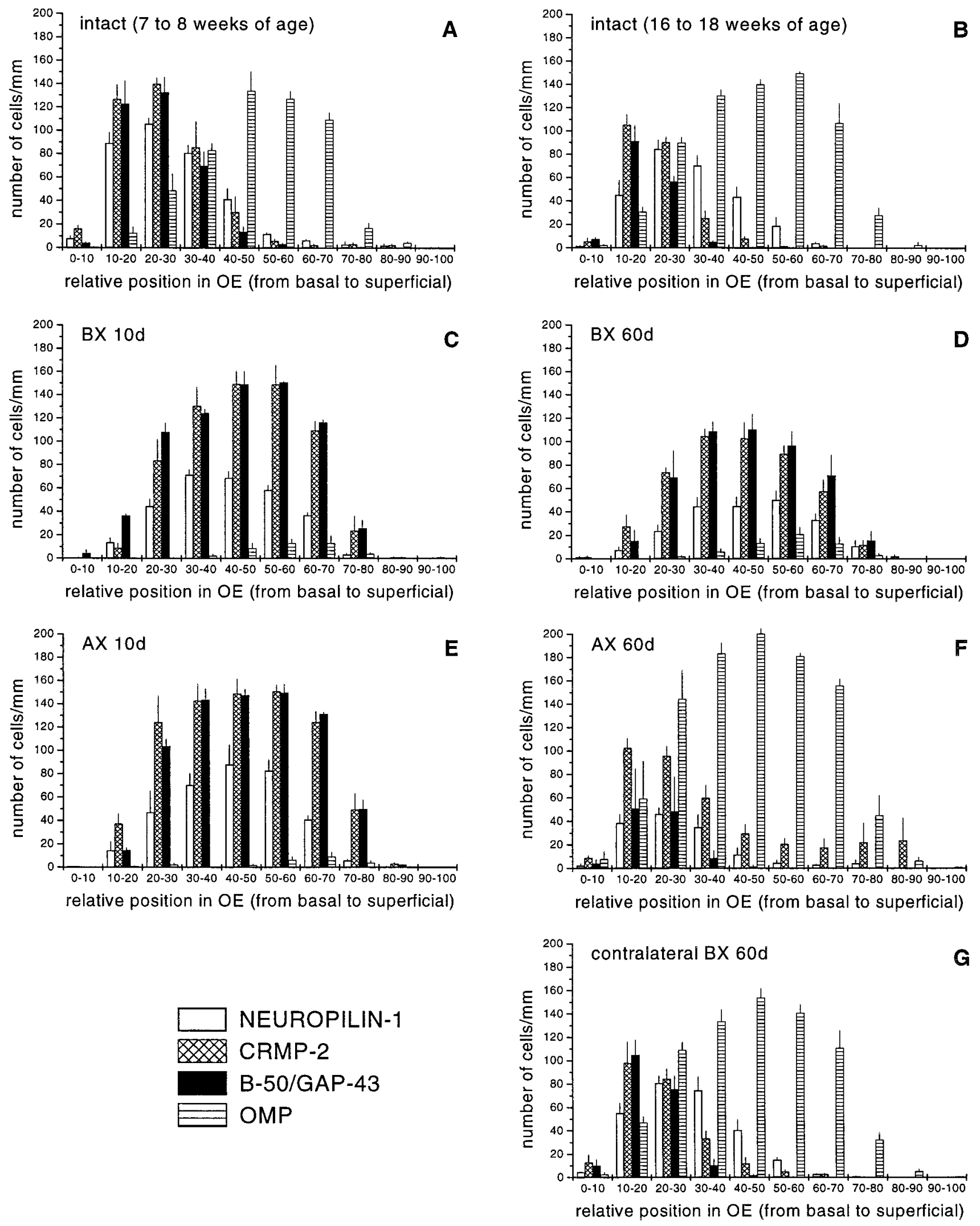

Figure 7. Quantitative assessment of the distribution of neuropilin-1, CRMP-2, B-50/GAP-43, and OMP-positive neurons in the intact and regenerating olfactory epithelium. The number and distribution of neuropilin-1 mRNA, CRMP-2 mRNA, B-50/GAP-43 mRNA, and OMP-positive olfactory receptor neurons were determined at the left side of the septal olfactory epithelium of unlesioned age-matched control animals of 7-8 weeks of age $(A)$, 16-18 weeks of age $(B)$, and at 10 and $60 \mathrm{~d}$ after bulbectomy $(C, D)$ or transection of the primary olfactory nerve $(E, F)$. (Figure legend continues) 


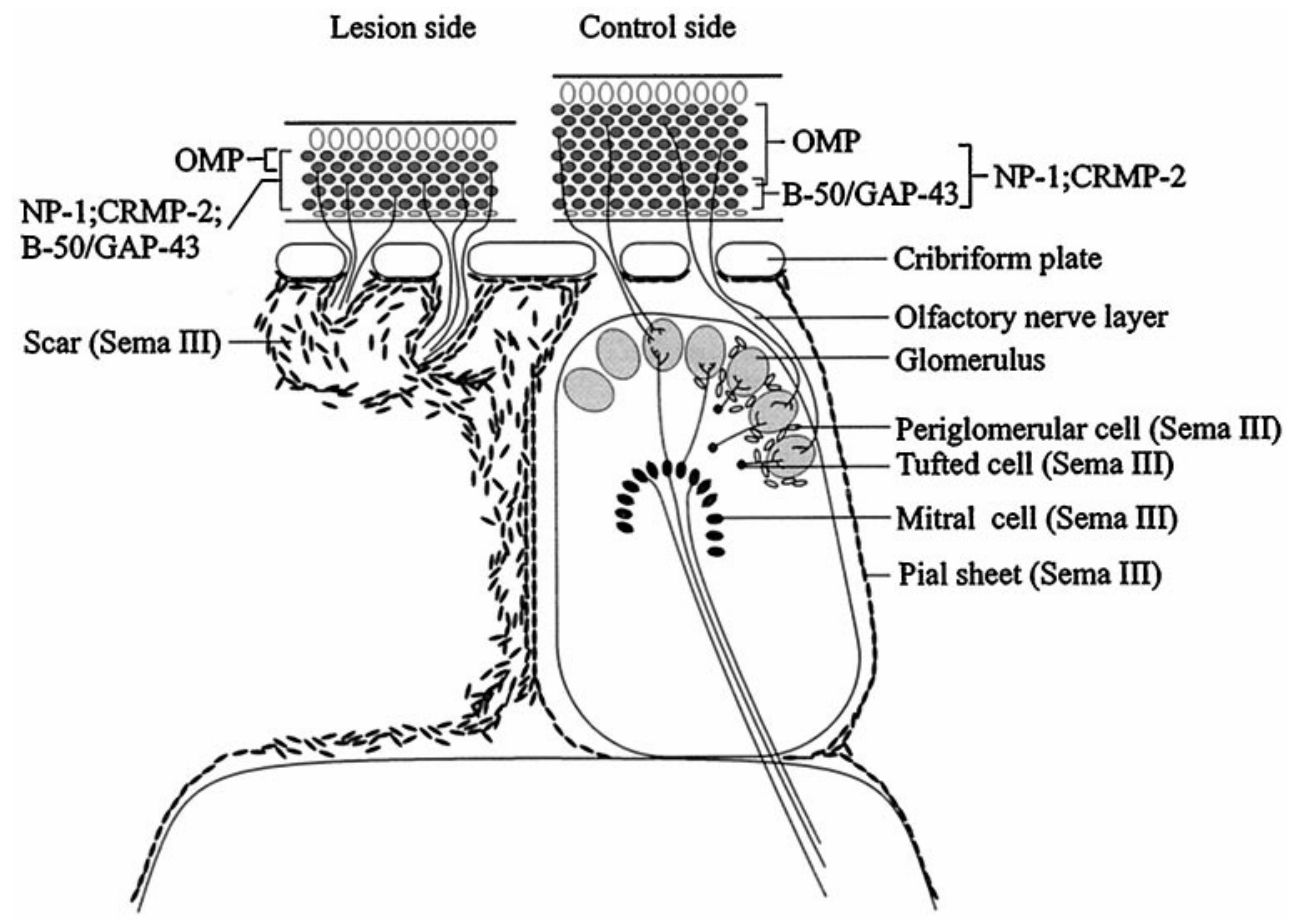

Figure 8. Proposed roles of semaphorin III-neuropilin-1 signaling during regeneration of the primary olfactory pathway. Scheme showing the intact (right) and lesioned (left, bulbectomy) olfactory system. The results show a complementary localization of sema III and its receptor neuropilin-1 in both the intact and regenerating adult olfactory system. We propose that sema III secreted by pial cells and second-order olfactory neurons of the intact olfactory system helps to confine continuously ingrowing neuropilin-1-positive olfactory axons to the olfactory nerve and glomerular layers, thereby determining the gross pattern of innervation of the olfactory bulb. After injury to the primary olfactory pathway, sema III-positive non-neuronal cells in the lesion site are present in close proximity to neuropilin-1-positive regenerating axons. Interestingly, the differential spatiotemporal expression of sema III after bulbectomy compared with axotomy appears to correlate to the regenerative potential displayed after these two types of lesions. The robust expression of sema III in scar tissue after bulbectomy and the failure of olfactory axons expressing the sema III receptor neuropilin-1 to regenerate across this scar suggests that the presence of semaphorins, i.e., sema III, in CNS scar tissue contributes to the regenerative failure of the injured CNS.

(Comeau et al., 1998) suggests that sema III signaling in neuropilin-1-negative olfactory axons may be mediated by other semaphorin receptors, such as plexins.

\section{Distinct patterns of expression of sema III after bulbectomy and axotomy}

Bulbectomy induces the formation of scar tissue, which constitutes a barrier to the extension of regenerating olfactory axons through the bulbar cavity into undamaged parts of the CNS, e.g., the frontal pole of the cortex (Monti Graziadei, 1983; Hendricks et al., 1994). After axotomy of the primary olfactory nerve, however, regenerating axons are capable of reinnervating their glomerular targets. Interestingly, when confronted with a transplanted optic nerve-derived glial scar, axotomized olfactory axons fail to regenerate as well (Anders and Hurlock, 1996). The failure of axons to regenerate through a scar, as observed after bulbectomy, has been observed in other CNS lesion models as well (Berry et al., 1983; Reier et al., 1983; Bovolenta et al., 1992) and has been attributed, in part, to growth-inhibitory molecules, including tenascin, proteoglycans, and myelin-derived glycoproteins (Rudge and Silver, 1990; Snow et al., 1990; McKeon et al., 1991; Laywell et al., 1992; Pindzola et al., 1993; Schwab et al., 1993; Steindler, 1993; Levine, 1994; Mukhopadhyay et al., 1994; Brodkey et al., 1995; Gates et al., 1996; Davies et al., 1997; Zhang et al., 1997). The current results show that, in addition to these growth-inhibitory molecules, high levels of sema III mRNA are present in CNS scar tissue.

At 1 and 2 months after bulbectomy, large numbers of sema III mRNA-containing cells occupy the scar and tightly encapsulate bundles of regenerating axons expressing the sema III receptor neuropilin-1. Preliminary observations suggest that the scarrelated sema III-positive cells are probably fibroblast-like cells of meningeal origin (Pasterkamp et al., 1997; R. J. Pasterkamp and J. Verhaagen, unpublished observations). The sensitivity of developing olfactory receptor neurons to sema III (Kobayashi et al., 1997) and the recapitulation of developmental patterns of neuropilin-1 and CRMP-2 expression after injury to the primary

\section{$\leftarrow$}

In addition, at $60 \mathrm{~d}$ after bulbectomy, the contralateral control side was analyzed $(G)$. For all groups, the number of animals analyzed was three. In young adult animals (7-8 weeks of age), the population of neuropilin-1- and CRMP-2 mRNA-positive neurons overlap almost completely with B-50/GAP-43 mRNA-expressing neurons $(A)$. In fully mature animals (16-18 weeks of age), the cohorts of neuropilin-1- and CRMP-2-expressing neurons overlap with B-50/GAP-43 immature neurons and with OMP-positive mature neurons immediately on top of these immature neurons $(B)$. At $10 \mathrm{~d}$ after bulbectomy and axotomy, cohorts of neuropilin-1 mRNA- and CRMP-2 mRNA-expressing neurons display almost complete overlap with B-50/GAP-43 mRNAcontaining neurons $(C, E)$. At $60 \mathrm{~d}$ after bulbectomy, patterns of expression for neuropilin-1 mRNA and CRMP-2 mRNA resemble those seen at $10 \mathrm{~d}$ after lesioning, although the total number of cells has slightly decreased $(D)$. The expression patterns in the contralateral side of the epithelium $(G)$ are indistinguishable from those of unlesioned control animals $(B)$. In contrast to bulbectomy, at $60 \mathrm{~d}$ after axotomy, expression patterns strongly resemble control $(F)$. $B X$, Bulbectomy; $A X$, axotomy. 
olfactory nerve suggest that regenerating olfactory receptor neurons are sensitive to sema III as they elaborate axons to the CNS. Increased or persistent expression of neuropilin-1 and CRMP-2 after nerve injury is consistent with observations in lesioned retinal ganglion, dorsal root ganglion, and motor neurons (Fujisawa et al., 1995, Minturn et al., 1995; Pasterkamp et al., 1998). It is tempting to speculate that sema III derived from non-neuronal cells in the scar generates a chemorepulsive barrier in the bulbar cavity that prevents extension of regenerating olfactory axons.

Interestingly, the sema III gene displays a differential spatiotemporal pattern of expression after bulbectomy compared with axotomy. After axotomy, sema III-positive cells are arranged in patches and strings caudal to the cribriform plate. Bundles of regenerating axons grow through sema III-free gaps in the lesion area to reach the intact nerve layer. The growth-permissive properties of the olfactory ensheathing cells (OEC) in the olfactory nerve layer are probably of critical importance to the successful regeneration of olfactory nerve bundles after axotomy (Doucette et al., 1983; Doucette, 1990; Ramón-Cueto and Valverde, 1995). OEC produce a variety of molecules, including CAMs, ECM components, and growth factors, supporting neurite outgrowth (Liesi, 1985; Miragall et al., 1988; Miragall and Dermietzel, 1992; Ramón-Cueto and Nieto-Sampedro, 1992; Ramón-Cueto et al., 1993; Franceschini and Barnett, 1996; Kafitz and Greer, 1998). Another beneficial effect related to OEC is their ability to penetrate glial scar tissue, enabling regenerative sprouts to pass through the nonpermissive lesion site (RamónCueto et al., 1998). Noticeably, transplantation of OEC in the injured spinal cord has resulted in considerable regeneration across a lesion that would otherwise not allow regeneration ( $\mathrm{Li}$ et al., 1997; Ramón-Cueto et al., 1998). Therefore, the removal of OEC as a result of bulbectomy may contribute to the failure of regenerating olfactory axons to cross CNS scar tissue. In contrast, the growth-permissive properties of OEC and the transient expression of sema III in non-neuronal cells associated with the lesion site after axotomy may, at least in part, account for the successful regeneration of axotomized olfactory axons.

In summary, our results show a complementary localization of sema III and its receptor neuropilin-1 in the intact and regenerating adult olfactory system (Fig. 8). We propose that sema III in the pial sheet and in second-order olfactory neurons of the intact olfactory system helps to confine ingrowing neuropilin-1-positive olfactory axons to the olfactory nerve and glomerular layers, thereby determining the gross pattern of innervation of the olfactory bulb. After injury to the primary olfactory pathway, sema III-positive non-neuronal cells appear in close proximity to neuropilin-1-positive regenerating axons. The differential spatiotemporal expression of sema III after bulbectomy compared with axotomy correlates with the differential regenerative potential observed after these lesions. Robust expression of the chemorepellent sema III in scar tissue after bulbectomy and the failure of neuropilin-1-expressing olfactory axons to regenerate across the sema III-positive cells in the scar may indicate that this semaphorin contributes to the growth-inhibitory nature of CNS scar tissue.

\section{REFERENCES}

Anders JJ, Hurlock JA (1996) Transplanted glial scar impedes olfactory bulb reinnervation. Exp Neurol 142:144-150.

Berry M, Maxwell WL, Logan A, Mathewson A, McConnell P, Ashhurst DE, Thomas GH (1983) Deposition of scar tissue in the central nervous system. Acta Neurochir Suppl 32:31-53.

Bovolenta P, Wandosell F, Nieto-Sampedro M (1992) CNS glial scar tissue: a source of molecules which inhibit central neurite outgrowth. Prog Brain Res 94:367-379.

Brodkey JA, Laywell ED, O’Brien TF, Faissner A, Stefansson K, Dorries HU, Schachner M, Steindler DA (1995) Focal brain injury and upregulation of a developmentally regulated extracellular matrix protein. J Neurosurg 82:106-112.

Buck L, Axel R (1991) A novel multigene family may encode odorant receptors: a molecular basis for odor recognition. Cell 65:175-187.

Carr VmcM, Walters E, Margolis FL, Farbman AI (1998) An enhanced olfactory marker protein immunoreactivity in individual olfactory receptor neurons following olfactory bulbectomy may be related to increased neurogenesis. J Neurobiol 34:377-390.

Chung WW, Lagenauer CF, Yan Y, Lund JS (1991) Developmental expression of neural cell adhesion molecules in the mouse neocortex and olfactory bulb. J Comp Neurol 314:290-305.

Comeau MR, Johnson R, DuBose RF, Petersen M, Gearing P, VandenBos T, Park L, Farrah T, Buller, RM, Cohen JI, Strockbin LD, Rauch C, Spriggs MK (1998) A poxvirus-encoded semaphorin induces cytokine production from monocytes and binds to a novel cellular semaphorin receptor, VESPR. Immunity 8:473-482.

Constanzo RM (1985) Neural regeneration and functional reconnection following olfactory nerve transection in hamster. Brain Res 361:258-266.

Danciger E, Mettling C, Vidal M, Morris R, Margolis F (1989) Olfactory marker protein gene: its structure and olfactory neuron-specific expression in transgenic mice. Proc Natl Acad Sci USA 86:8565-8569.

Davies SJA, Fitch MT, Memberg SP, Hall AK, Raisman G, Silver J (1997) Regeneration of adult axons in white matter tracts of the central nervous system. Nature 390:680-683.

Doucette JR (1990) Glial influences on axonal growth in the primary olfactory system. Glia 3:433-449.

Doucette JR (1996) Immunohistochemical localization of laminin, fibronectin and collagen type IV in the nerve layer of the olfactory bulb. Int J Neurosci 14:945-959.

Doucette JR, Kiernan JA, Flumerfelt BA (1983) The re-innervation of olfactory glomeruli following transection of primary olfactory axons in the central or peripheral nervous system. J Anat 137:1-19.

Farbman AI (1990) Olfactory neurogenesis: genetic or environmental controls? Trends Neurosci 13:362-365.

Farbman AI (1992) Cell biology of olfaction. New York: Cambridge UP.

Farbman AI, Margolis FL (1980) Olfactory marker protein ontogeny: immunohistochemical localization. Dev Biol 74:205-215.

Feiner L, Koppel AM, Kobayashi H, Raper JA (1997) Secreted semaphorins bind recombinant neuropilin with similar affinities but bind different subsets of neurons in situ. Neuron 19:539-545.

Franceschini IA, Barnett SC (1996) Low-affinity NGF-receptor and E-N-CAM expression define two types of olfactory nerve ensheating cells that share a common lineage. Dev Biol 173:327-343.

Fujisawa H, Takagi S, Hirata T (1995) Growth-associated expression of a membrane protein, neuropilin, in Xenopus optic nerve fibers. Dev Neurosci 17:343-349.

Gates MA, Fillmore H, Steindler DA (1996) Chondroitin sulfate proteoglycan and tenascin in the wounded adult mouse neostriatum in vitro: dopamine neuron attachment and process outgrowth. J Neurosci 16:8005-8018.

Giger RJ, Wolfer DP, de Wit GMJ, Verhaagen J (1996) Anatomy of rat semaphorin III/collapsin-1 mRNA expression and relationship to developing nerve tracts during neuroembryogenesis. J Comp Neurol 375:378-392.

Giger RJ, Pasterkamp RJ, Heijnen S, Holtmaat AJGD, Verhaagen J (1998) Anatomical distribution of the chemorepellent semaphorin III/ collapsin-1 in the adult rat and human brain: predominant expression in structures of the olfactory-hippocampal pathway and the motor system. J Neurosci Res 52:27-42.

Gong Q, Shipley MT (1995) Evidence that pioneer olfactoy axons regulate telencephalon cell cycle kinetics to induce the formation of the olfactory bulb. Neuron 14:91-101.

Gong Q, Shipley MT (1996) Expression of extracellular matrix molecules and cell surface molecules in the olfactory nerve pathway during early development. J Comp Neurol 366:1-14.

Gonzalez M de L, Malemud CJ, Silver J (1993) Role of astroglial extracellular matrix in the formation of the rat olfactory bulb glomeruli. Exp Neurol 123:91-105.

Goshima Y, Nakamura F, Strittmatter P, Strittmatter SM (1995) 
Collapsin-induced growth cone collapse mediated by an intracellular protein related to UNC-33. Nature 376:509-514.

Graziadei PPC (1990) Olfactory development. In: Development of sensory systems in mammals (Coleman J, ed), pp 519-568. New York: Wiley.

Graziadei PPC, Monti Graziadei GA (1978) Continuous nerve cell renewal in the olfactory system. In: Handbook of sensory physiology: development of sensory system (Jacobson M, ed), pp 55-83. Berlin: Springer.

Graziadei PPC, Monti Graziadei GA (1980) Neurogenesis and neuron regeneration in the olfactory system of mammals. III. Deafferentation and reinnervation of the olfactory bulb following section of the fila olfactoria in rat. J Neurocytol 9:145-162.

Harding J, Graziadei PPC, Monti Graziadei GA, Margolis FL (1977) Denervation in the primary olfactory pathway of mice. IV. Biochemical and morphological evidence for neuronal replacement following nerve section. Brain Res 132:11-28.

He Z, Tessier-Lavigne M (1997) Neuropilin is a receptor for the axonal chemorepellent semaphorin III. Cell 90:739-751.

Hendricks KR, Kott JN, Lee ME, Gooden MD, Evers SM, Westrum LE (1994) Recovery of olfactory behavior. I. Recovery after complete olfactory bulb lesion correlates with patterns of olfactory nerve penetration. Brain Res 648:121-133.

Holtmaat AJGD, Dijkhuizen PA, Oestreicher AB, Romijn HJ, Van der Lugt NMT, Berns A, Margolis FL, Gispen WH, Verhaagen J (1995) Directed expression of the growth-associated protein B-50/GAP-43 to olfactory neurons in transgenic mice results in changes in axon morphology and extraglomerular fiber growth. J Neurosci 15:7953-7965.

Holtmaat AJGD, Hermens WTJMC, Sonnemans MAF, Giger RJ, Van Leeuwen FW, Kaplitt MG, Oestreicher AB, Gispen WH, Verhaagen J (1997) Adenoviral vector-mediated expression of B-50/GAP-43 induces alterations in the membrane organization of olfactory axon terminals in vivo. J Neurosci 17:6575-6586.

Julliard AK, Hartmann DJ (1998) Spatiotemporal patterns of expression of extracellular matrix molecules in the developing and adult rat olfactory system. Neuroscience 84:1135-1150.

Kafitz KW, Greer CA (1998) Differential expression of extracellular matrix and cell adhesion molecules in the olfactory nerve and glomerular layers of adult rats. J Neurobiol 34:271-282.

Kamata T, Subleski M, Hara Y, Yuhki N, Kung H, Copeland NG, Jenkins NA, Yoshimura T, Modi W, Copeland TD (1998) Isolation and characterization of a bovine neural specific protein (CRMP-2) cDNA homologous to unc-33, a C. elegans gene implicated in axonal outgrowth and guidance. Mol Brain Res 54:219-236.

Kawakami A, Kitsukawa T, Takagi S, Fujisawa H (1996) Developmentally regulated expression of a cell surface protein, neuropilin, in the mouse nervous system. J Neurobiol 29:1-17.

Keller A, Margolis FL (1975) Immunological studies of the rat olfactory marker protein. J Neurochem 24:1101-1106.

Kobayashi H, Koppel AM, Luo Y, Raper JA (1997) A role for collapsin-1 in olfactory and cranial sensory axon guidance. J Neurosci 17:8339-8352.

Kolodkin AL, Ginty DD (1997) Steering clear of semaphorins: neuropilins sound the retreat. Neuron 19:1159-1162.

Kolodkin AL, Matthes DJ, O'Connor TP, Patel NP, Admon A, Bently D, Goodman CS (1992) Fasciclin IV: sequence, expression, and function during growth cone guidance in the grasshopper embryo. Neuron 9:831-845.

Kolodkin AL, Matthes DJ, Goodman CS (1993) The semaphorin genes encode a family of transmembrane and secreted growth cone guidance molecules. Cell 75:1389-1399.

Kolodkin AL, Levengood DV, Rowe EG, Tai Y-T, Giger RJ, Ginty DD (1997) Neuropilin is a semaphorin III receptor. Cell 90:753-762.

Koppel AM, Feiner L, Kobayashi H, Raper JA (1997) A 70 amino acid region within the semaphorin domain activates specific cellular response of semaphorin family members. Neuron 19:531-537.

Krull CE, Morton DB, Faissner A, Schachner M, Tolbert LP (1994) Spatiotemporal pattern of expression of tenascin-like molecules in a developing insect olfactory system. J Neurobiol 25:515-534.

Laywell ED, Dorries U, Bartsch U, Faissner A, Schachner M, Steindler DA (1992) Enhanced expression of the developmentally regulated extracellular matrix molecule tenascin following adult brain injury. Proc Natl Acad Sci USA 89:2634-2638.

Levine JM (1994) Increased expression of NG2 chondroitin-sulfate proteoglycan after brain injury. J Neurosci 14:4716-4730.
Li Y, Field PM, Raisman G (1997) Repair of adult rat corticospinal tract by transplants of olfactory ensheating cells. Science 277:2000-2002.

Liesi P (1985) Laminin immunoreactive glia distinguish regenerative adult CNS systems from non-regenerative ones. EMBO J 4:2505-2511.

Livesey FJ, Hunt SP (1997) Netrin and netrin receptor expression in the embryonic mammalian nervous system suggests roles in retinal, striatal, nigral, and cerebella development. Mol Cell Neurosci 8:417-429.

Luo Y, Raible D, Raper JA (1993) Collapsin: a protein in the brain that induces the collapse and paralysis of neuronal growth cones. Cell 75:217-227.

Luo Y, Sheperd I, Li J, Renzi MJ, Chang S, Raper JA (1995) A family of molecules related to collapsin in the embryonic chick nervous system. Neuron 14:1131-1140.

Margolis FL (1985) Olfactory marker protein: from PAGE band to cDNA clone. Trends Neurosci 10:542-546.

McKeon RJ, Schreiber RC, Rudge JS, Silver J (1991) Reduction of neurite outgrowth in a model of glial scarring following CNS injury is correlated with the expression of two inhibitory molecules on reactive astrocytes. J Neurosci 11:3398-3411.

Meiri KF, Bickerstaff LE, Schwob JE (1991) Monoclonal antibodies show that kinase $\mathrm{C}$ phosphorylation of GAP-43 during axogenesis is both spatially and temporally restricted in vivo. $\mathrm{J}$ Cell Biol 112:991-1005.

Minturn JE, Fryer HJL, Geschwind DH, Hockfield S (1995) TOAD-64, a gene expressed early in neuronal differentiation in the rat, is related to $u n c-33$, a $C$. elegans gene involved in axon outgrowth. J Neurosci 15:6757-6766.

Miragall F, Dermietzel R (1992) Immunocytochemical localization of cell adhesion molecules in the developing and mature olfactory system. Microsc Res Tech 23:157-172.

Miragall F, Monti Graziadei GA (1982) Experimental studies on the olfactory marker protein. II. Appearance of the olfactory marker protein during differentiation of the olfactory sensory neurons of mouse: an immunohistochemical and autoradiographic study. Brain Res 329:245-250.

Miragall F, Kadmon G, Husman M, Schachner M (1988) Expression of cell adhesion molecules in the olfactory system of the adult mouse: presence of embryonic form of N-CAM. Dev Biol 129:516-531.

Miragall F, Kadmon G, Schachner M (1989) Expression of L1 and N-CAM cell adhesion molecules during development of the mouse olfactory system. Dev Biol 135:272-286.

Mombaerts P, Wang F, Dulac C, Chao SK, Nemes A, Mendelson M, Edmondson J, Axel R (1996) Visualizing an olfactory sensory map. Cell 87:675-686.

Monti Graziadei GA (1983) Experimental studies on the olfactory marker protein. III. The olfactory marker protein in the olfactory neuroepithelium lacking connections with the forebrain. Brain Res 262:303-308.

Monti Graziadei GA, Graziadei PPC (1979) Neurogenesis and neuron regeneration in the olfactory system of mammals. II. Degeneration and reconstitution of the olfactory sensory neurons after axotomy. J Neurocytol 8:197-213.

Monti Graziadei GA, Stanley RS, Graziadei PPC (1980) The olfactory marker protein in the olfactory system of mouse during development. Neuroscience 5:1239-1252.

Mori K (1993) Molecular and cellular properties of mammalian primary olfactory axons. Microsc Res Tech 24:131-141.

Mukhopadhyay G, Doherty P, Walsh FS, Crocker PR, Filbin MT (1994) A novel role for myelinated-associated glycoprotein as an inhibitor of axonal regeneration. Neuron 13:757-767.

Nielander HL, Schrama LH, Van Rozen AJ, Kasperaitis M, Oestreicher AB, de Graan PNE, Gispen WH, Schotman P (1987) Primary structure of the neuron-specific phosphoprotein B50 is identical to growthassociated protein GAP 43. Neurosci Res Commun 1:163-172.

Oestreicher AB, Van Dongen CJ, Zwiers H, Gispen WH (1983) Affinity purified anti-B-50 protein antibody: interference with the function of the phosphoprotein B-50 in synaptic plasma membranes. J Neurochem 41:331-340.

Ohta K, Mizutani A, Kawakami A, Murakami Y, Kasuya Y, Takagi S, Tanaka H, Fujisawa H (1995) Plexin: a novel neuronal cell surface molecule that mediates cell adhesion via a homophilic binding mechanism in the presence of calcium ions. Neuron 14:1189-1199.

Pasterkamp RJ, Giger RJ, Verhaagen J (1997) Induction of semaphorin(D)III/collapsin-1 mRNA expression in leptomeningeal cells during scar formation. Soc Neurosci Abstr 23:614. 
Pasterkamp RJ, Giger RJ, Verhaagen J (1998) Regulation of semaphorin III/collapsin-1 gene expression during peripheral nerve regeneration. Exp Neurol, in press.

Pindzola RR, Doller C, Silver J (1993) Putative inhibitory extracellular matrix molecules at the dorsal root entry zone of the spinal cord during development and after root and sciatic nerve lesions. Dev Biol 156:34-48.

Püschel AW (1996) The semaphorins: a family of axonal guidance molecules? Eur J Neurosci 8:1317-1321.

Püschel AW, Adams RH, Betz H (1995) Murine semaphorin D/collapsin is a member of a diverse gene family and creates domains inhibitory for axonal extension. Neuron 14:941-948.

Ramón-Cueto A, Nieto-Sampedro M (1992) Glial cells from adult rat olfactory bulb: immunocytochemical properties of pure cultures of ensheating cells. Neuroscience 47:213-220.

Ramón-Cueto A, Valverde F (1995) Olfactory bulb ensheating glia: a unique cell type with axonal growth-promoting properties. Glia 14:163-173.

Ramón-Cueto A, Pérez J, Nieto-Sampedro M (1993) In vitro enfolding of olfactory neurites by p75 NGF receptor positive ensheating cells from adult rat olfactory bulb. Eur J Neurosci 5:1172-1180.

Ramón-Cueto A, Plant GW, Avilla J, Bunge MB (1998) Long-distance axonal regeneration in the transected adult rat spinal cord is promoted by olfactory ensheating glia transplants. J Neurosci 18:3803-3815.

Reier PJ, Stensaas LJ, Guth L (1983) The astrocytic scar as an impediment to regeneration in the central nervous system. In: Spinal cord reconstruction (Cao CC, Bunge RP, eds), pp 163-198. New York: Raven.

Ressler KJ, Sullivan SL, Buck LB (1993) A zonal organization of odorant receptor gene expression in the olfactory epithelium. Cell 73:597-609.

Rudge JS, Silver J (1990) Inhibition of neurite outgrowth on astroglial scars in vitro. J Neurosci 10:3594-3603.

Satoda M, Takagi S, Ohta K, Hirata T, Fujisawa H (1995) Differential expression of two cell surface proteins, neuropilin and plexin, in $\mathrm{Xe}$ nopus olfactory axon subclasses. J Neurosci 15:942-955.

Schaeren-Wiemers N, Gerfin-Moser A (1993) A single protocol to detect transcripts of various types and expression levels in neural tissue and cultured cells: in situ hybridization using digoxigenin-labeled cRNA probes. Histochemistry 100:431-440.

Schwab ME, Kapf hammer JP, Bandtlow CE (1993) Inhibitors of neurite growth. Annu Rev Neurosci 16:565-595.

Schwob JE, Mieleszko KE, Szumowski M, Stasky AA (1992) Olfactory sensory neurons are trophically dependent on the olfactory bulb for their prolonged survival. J Neurosci 12:3896-3919.

Sheperd GM (1972) Synaptic organization of the mammalian olfactory bulb. Physiol Rev 52:864-917.

Sheperd I, Luo Y, Raper JA, Chang S (1996) The distribution of collapsin-1 mRNA in the developing chick nervous system. Dev Biol 173:185-199.

Shipley MT, Ennis M (1996) Functional organization of olfactory system. J Neurobiol 30:123-176.

Snow DM, Lemmon V, Carrino DA, Kaplan AI, Silver J (1990) Sulfated proteoglycans in astroglial barriers inhibit neurite outgrowth in vitro. Exp Neurol 109:111-130.

Steindler DA (1993) Glial boundaries in the developing nervous system. Annu Rev Neurosci 16:445-470.

Strottmann J, Wanner I, Helfrich T, Beck A, Breer H (1994) Rostrocaudal patterning of receptor expressing neurones in the rat nasal cavity. Cell Tissue Res 278:11-20.

Takagi S, Hirata T, Agata K, Mochii M, Eguchi G, Fujisawa H (1991) The A5 antigen, a candidate for the neuronal recognition molecule, has homologies to complement components and coagulation factors. Neuron 7:295-307.

Treolar HB, Nurcombe V, Key B (1996) Expression of extracellular matrix molecules in the embryonic rat olfactory pathway. J Neurobiol 31:41-55.

Vassar R, Ngai J, Axel R (1993) Spatial segregation of odorant receptor expression in the mammalian olfactory epithelium. Cell 74:309-318.

Verhaagen J, Oestreicher AB, Gispen WH, Margolis FL (1989) The expression of the growth associated protein B-50/GAP-43 in the olfactory system of neonatal and adult rats. J Neurosci 9:683-691.

Verhaagen J, Oestreicher AB, Grillo M, Khew-Goodall Y-S, Gispen WH, Margolis FL (1990) Neuroplasticity in the olfactory system: differential effects of central and peripheral lesions of the primary olfactory pathway on the expression of B-50/GAP-43 and the olfactory marker protein. J Neurosci Res 26:31-44.

Wang L-H, Strittmatter SM (1996) A family of rat CRMP genes is differentially expressed in the nervous system. J Neurosci 16:6197-6207.

Whitesides JG, LaMantia A-S (1996) Differential adhesion and the initial assembly of the mammalian olfactory nerve. J Comp Neurol 373:240-254.

Williams-Hogarth LC, Torrey C, Cai X, Kolodkin AL, Ronnett GV (1997) Semaphorin expression in the developing and regenerating primary olfactory pathway. Soc Neurosci Abstr 23:613.

Winberg ML, Mitchell KJ, Goodman CS (1998) Genetic analysis of the mechanisms controlling target selection: complementary and combinatorial functions of netrins, semaphorins, and IgCAMs. Cell 93:581-591.

Yoshida K, Püschel AW, Schwarting GA (1997) Semaphorins are differentially expressed during development of the rat olfactory system. Soc Neurosci Abstr 23:613.

Yoshihara Y, Mori K (1997) Basic principles and molecular mechanisms of olfactory axon pathfinding. Cell Tissue Res 290:457-463.

Yoshihara Y, Kawasaki M, Tamada A, Fujita H, Hayashi H, Kagamiyama H, Mori K (1997) OCAM: a new member of the neural cell adhesion molecule family related to zone-to-zone projection of olfactory and vomeronasal axons. J Neurosci 17:5830-5842.

Zhang J-H, Cerretti DP, Yu T, Flanagan JG, Zhou R (1996) Detection of ligands in regions anatomically connected to neurons expressing the Eph receptor Bsk: potential roles in neuron-target interaction. J Neurosci 16:7182-7192.

Zhang Y, Winterbottom JK, Schachner M, Lieberman AR, Anderson PN (1997) Tenascin-C expression and axonal sprouting following injury to the spinal dorsal columns in the adult rat. J Neurosci Res 49:433-450. 